\title{
Engajamento e redução do espaço dialógico no gênero noticia de popularização cientifica
}

\author{
Engagement and reduction of dialogic space \\ in the science popularization news genre
}

\author{
Anelise Scotti Scherer \\ Universidade Federal de Santa Maria \\ Désirée Motta-Roth \\ Universidade Federal de Santa Maria
}

Resumo: A popularização da ciência (PC) envolve um processo complexo de recontextualização, no qual o discurso científico, produzido por especialistas, é recontextualizado por jornalistas para uma audiência não especializada, em gêneros discursivos da mídia de massa. Pesquisas recentes têm apontado um efeito de monologismo em notícias de PC em português (MOTTA-ROTH; LOVATO, 2011 conforme MOIRAND, 2003) e inglês (MOTTA-ROTH; MARCUZZO, 2010), nas quais há um predomínio da voz da ciência e um apagamento de outras vozes possíveis como o governo ou o público, já identificados na mídia de PC francesa (BEACCO et al., 2002; MOIRAND, 2003). Com base em estudos prévios, o objetivo do presente artigo é apresentar uma análise engajamento discursivo e do jogo entre expansão e contração dialógica em 45 notícias de PC em inglês. Para tanto, consideramos os Sistemas de Transitividade e de Modalidade (HALLIDAY; MATTHIESSEN, 2004) e o Sistema de Avaliatividade (MARTIN; WHITE, 2005) da Linguística SistêmicoFuncional para a análise. Nossos resultados indicam que, apesar da maior recorrência de expoentes linguísticos que sugerem expansão dialógica por meio de reconhecimento, não há indicação clara de debate entre pontos de vista diferentes em nosso corpus, a não ser aqueles associados a especialistas/pesquisadores. Nesse sentido, o jornalista/autor da notícia contrai o espaço dialógico do discurso ao enfatizar a voz da ciência e, ao mesmo 
tempo, restringir a participação de outros setores da sociedade no debate em potencial sobre a pesquisa popularizada (MARCUZZO, 2011), reforçando, assim, a hegemonia da voz da ciência na mídia de massa.

Palavras-chave: Popularização da ciência. Análise Crítica de Gênero. Linguística Sistêmico-Funcional. Subsistema de engajamento. Dialogismo e efeito de monologismo.

Anelise Abstract: Science popularization (SP) involves a complex process of recontextualization, Scotti Scherer through which scientific discourse, produced by specialists, is recontextualized by journalists to a non-specialized audience in mass media discourse genres. Recent research

Désirée has indicated an effect of monologism in SP News in Portuguese (MOTTA-ROTH; LOVATO, Motta-Roth 2011 in accordance with MOIRAND, 2003) and in English (MOTTA-ROTH; MARCUZZO, 2010), in which there is predominance of the voice of science and delition of other possible voices such as the government and the public as already identified in the French SP media (BEACCO et al., 2002; MOIRAND, 2003). Based on previous studies, the objective of the present article is to present an analysis of the discursive engagement and the interplay between dialogic expansion and contraction in 45 SP news texts in English. To do so we consider the Transitivity and Modality Systems (HALLIDAY; MATTHIESSEN, 2004) and the Appraisal System (MARTIN; WHITE, 2005) from Systemic-Functional Linguistics for the analysis. Our results indicate that, apart from a major recurrence of linguistic exponents which suggest dialogic expansion through acknowledgement, there is no clear indication of debate between different points of view in our corpus, except from those associated with specialists/scientists. In that respect, the journalist/news author contracts the dialogic space in discourse by emphasizing the voice from science and the same time by limiting the participation of other sectors of society in the potential debate about the popularized research (MARCUZZO, 2011), thus reinforcing the hegemony of the scientific voice in the mass media.

Key words: Science popularization. Critical Genre Analysis. Systemic-Functional Linguistics. Engagement subsystem. Dialogism and effect of monologism.

\section{Introdução}

A popularização da ciência $(\mathrm{PC})$ envolve recontextualização, um processo no qual o discurso científico produzido por especialistas é descontextualizado, por jornalistas, de seu contexto primário de produção da ciência e recontextualizado em gêneros discursivos da mídia de massa, para uma audiência não especializada (MOTTA-ROTH, 2009). Análises anteriores de notícias de PC em português (MOTTA-ROTH; LOVATO, 2011) e inglês (MOTTA-ROTH; MARCUZZO, 2010; MOTTA-ROTH, SCHERER, 2012) têm 
apontado um predomínio da voz de atores sociais identificados com a esfera científica e um apagamento de outras vozes possíveis, como de atores sociais do governo ou do público, causando um efeito de monologismo por fechamento do espaço de diálogo (MOIRAND, 2003). Nesse caso, o discurso da ciência torna-se uma voz prevalente e categórica, que não estabelece tensão com outras vozes possíveis. Assim, o discurso dessas notícias de PC parece fugir ao princípio dialógico da linguagem (VOLOCHINOV, 1995; BAKHTIN, 2010), pelo qual todo discurso responde ao já-dito e provocam respostas (adesões, recusas, aplausos, críticas, etc.) (FARACO, 2009, p. 58-9), ao reforçar a hegemonia da voz da ciência na mídia de massa.

Com base nesses estudos e considerando os Sistemas de Transitividade, Modalidade (HALLIDAY; MATTHIESSEN, 2004) e Avaliatividade (MARTIN; WHITE, 2005) da Linguística Sistêmico-Funcional, o objetivo deste artigo é apresentar uma análise dos expoentes linguísticos constitutivos de expansão e contração dialógica em 45 notícias de PC em inglês. Apresentamos o funcionamento desses expoentes linguísticos na notícia de PC - um gênero que entrecruza discursos de diferentes esferas de atividade humana, como a jornalística e a científica - a partir do exame dos expoentes linguísticos de projeção, os quais realizam a recontextualização do discurso nesses textos. Buscamos fornecer evidências linguísticas do efeito de monologismo em notícias de PC em inglês e avançar nossa análise prévia (MOTTA-ROTH; SCHERER, 2012).

Este artigo está organizado em três seções principais em que apresentamos: a revisão dos fundamentos teóricos da pesquisa sobre recontextualização em notícias de PC (seção 1); os procedimentos adotados para a seleção do universo de análise, a delimitação do corpus e para as análises textual e contextual (seção 2); os resultados das análises (seção 3). Nossa conclusão evidencia o fato de que recursos tipicamente identificados pela Linguística Sistêmico-Funcional como expoentes de expansão dialógica efetivamente criam um efeito de monologismo em notícias de $\mathrm{PC}$, já que estão recursivamente associados à voz exclusiva do especialista/pesquisador. Essa escuta exclusiva da voz da ciência entra em conflito com a função da PC de oferecer um espaço de informação, educação e esclarecimento e principalmente de debate sobre o valor da empreitada científica para apoiar a participação do conjunto mais amplo da sociedade. 


\section{Pressupostos teórico-metodológicos}

\subsection{A recontextualização do discurso científico e a notícia de popularização da ciência}

Neste estudo, a PC é vista, ao mesmo tempo, como um dos processos envolvidos no panorama mais geral da cultura científica e como um processo de recontextualização do discurso produzido no contexto cientí-

Anelise fico em gêneros discursivos dedicados a audiências de não especialistas Scotti Scherer

Désirée (MOTTA-ROTH, 2009, com base em BERNSTEIN, 1974), como a notícia de PC e a reportagem didática (ver, por exemplo, PINTON, 2013).

Motta-Roth

Considerada como parte do todo que constitui a cultura científica, em que atores sociais engajam-se em práticas sociais relativas à ciência em diferentes esferas, a PC se localiza em uma espiral da cultura científica (MOREIRA, 2012, a partir de VOGT, 2003 e MOTTA-ROTH, 2009) que atravessa contextos ora mais identificados com a ciência, ora mais alinhados com sua popularização. Segundo Hilgartner (1990, p. 528), podemos identificar as diferenças relativas aos contextos em que o conhecimento científico é apresentado em termos de gradação, como um contínuo entre cientificidade e popularização. Esse contínuo faz referência à fluidez das fronteiras entre o conhecimento científico "genuíno" e a popularização, localizando gêneros como o artigo acadêmico, o livro didático e a notícia de PC em diferentes estágios desse contínuo.

Em tese, no contexto mediador da mídia de massa, os gêneros de PC oferecem à sociedade o acesso ao conhecimento científico em sua versão não especializada, ressaltando seu significado e fornecendo subsídios para que não especialistas possam participar mais ou menos ativamente nas decisões políticas acerca dos rumos da ciência (CALSAMIGLIA; VAN DIJK, 2004, p. 370). Essa visão do processo de PC pressupõe que a ciência perpasse os discursos da vida diária (BEACCO et al., 2002, p. 279) e forneça explicações para eventos recorrentes na vida em sociedade. Nesses termos, o processo de PC congregaria a ciência (a), a pedagogia (b) e o jornalismo (c) para desempenhar três funções (MOTTA-ROTH, 2009, p. 4):

a) informar segmentos não especializados da sociedade sobre novos resultados das pesquisas científicas;

b) educar a sociedade mais ampla, por meio da explicação de princípios e conceitos, para participar da apropriação e da transformação do conhecimento; 
c) esclarecer a relevância da pesquisa para instruir a sociedade sobre a necessidade de financiamento da empreitada científica.

Essas funções determinariam as escolhas léxico-gramaticais do jornalista e as estratégias linguísticas usadas na produção de textos referentes a um gênero de PC como a notícia, por exemplo. Nesse cenário, a mídia assume função de fórum, pois "atua como um instrumento poderoso para mobilizar o engajamento da sociedade no discurso da ciência ao promover debates que incluam os vários segmentos da sociedade" (MOTTA-ROTH, 2009, p. 137-138; com base em BERTRAND, 1999, p. 158). Para assegurar essa função de fórum, é esperado que pontos de vista de diferentes setores da sociedade sejam articulados, combinados ou contrastados em gêneros midiáticos. No caso da notícia, o autor pu-

Engajamento e redução do espaço dialógico no gênero notícia de popularização científica blica, em um veículo autodefinido como de PC, um relato sobre uma pesquisa recente de interesse para a comunidade-alvo da publicação. Esse relato caracteriza-se, entre outras coisas, pela apresentação das reações e dos comentários de diferentes atores sociais sobre a relevância ou o significado dos resultados dessa pesquisa para a vida em sociedade (MOREIRA; MOTTA-ROTH, 2008, com base em VAN DIJK, 1999, p.147).

Com base em um corpus de notícias de PC em inglês e em português, Motta-Roth e Lovato (2009, p. 259-260) identificaram que esse gênero

\begin{abstract}
[...] comumente traz informações relativas à síntese dos resultados [...] no lide, seguida pela apresentação da pesquisa [...], geralmente ou por detalhamento do lide, alusão ao autor e/ou descrição da metodologia, acompanhada por uma contextualização do estudo [...]. Na sequência, são detalhados os dados e os procedimentos metodológicos adotados [...]. Os últimos dois estágios textuais explicam os resultados [...] e as conclusões da pesquisa [...]. Perpassando todo o texto, há comentários que expressam pontos de vista que avaliam a pesquisa [...], e explicações de princípios e conceitos [...], quando o jornalista julga necessário explicar termos e/ou ideias para facilitar a leitura do conteúdo científico da notícia.
\end{abstract}

Esses movimentos retóricos encontrados nas notícias de PC são configurados pela léxico-gramática e por estratégias discursivas - tais como definição, exemplificação e metáfora. $\mathrm{O}$ autor dessas notícias de PC - normalmente um jornalista especializado (GERHARDT, 2011) - 
Anelise Scotti Scherer

Désirée Motta-Roth

promove o debate sobre o novo estudo ao estabelecer relações entre seu texto e textos de outros atores sociais pela inserção de diferentes vozes, por meio de citação e relato (BEACCO et al., 2002; OLIVEIRA; PAGANO, 2006; MOTTA-ROTH et al., 2008). Tais estratégias intertextuais caracteristicamente demarcam a retomada, pelo jornalista, de textos anteriores dos âmbitos científico (p. ex., artigos acadêmicos e comentários de especialistas) e não científico (p. ex., documentos governamentais e comentários do público em geral), para esclarecer a relevância da pesquisa e promover o debate sobre o modo como achados científicos podem afetar a sociedade (MOTTA-ROTH et al., 2008; SCHERER, 2013). Esses recursos constroem uma ponte de comunicação para que o leitor não especialista possa relacionar-se com temas normalmente tratados com terminologia e nomenclatura técnicas (PAGANO, 1998, p. 58-60).

Em estudos prévios sobre intertextualidade em notícias de PC, são identificadas cinco vozes ou posições enunciativas: o pesquisador (especialista que assume autoria do estudo), o colega (especialista na área ou área afim que não participou do estudo), o governo (representante oficial do governo), o público (não especialista) e o jornalista (profissional do contexto mediador, autor da notícia de PC) (MOTTA-ROTH et al., 2008; MOTTA-ROTH; LOVATO, 2009; LOVATO, 2010; MARCUZZO, 2011). Dessas cinco posições enunciativas, duas são mais frequentes e detêm lugar de destaque nos textos: o pesquisador e o colega. Nesse sentido, além de privilegiar o contexto científico, a multiplicidade de vozes não instaura um debate propriamente dito, servindo apenas para "fornecer informação relacionada ao tópico da notícia" (MARCUZZO, 2011, p. 160).

Podemos considerar, portanto, que, em se tratando de PC, há uma incongruência entre o papel da mídia como fórum - o qual pressupõe que se publiquem "pontos de vista, especialmente se forem opostos" (MOTTA-ROTH, 2009, p. 137; citando BERTRAND, 1999, p. 158) - e o modo como diferentes posições enunciativas são comumente mobilizadas. Em vez de promover um debate em que diferentes representantes da sociedade podem opinar sobre ciência, as notícias de PC, coletadas pelo GT-LABLER nas revistas online ABC Science, BBC News, Nature News, Scientific American, Ciência Hoje e Galileu, reforçam o discurso hegemônico da ciência ao priorizar um ponto de vista: o científico.

Além da alternância de vozes, outro aspecto que tipicamente marca a coexistência de diferentes pontos de vista no gênero notícia de PC é a modalização. Segundo Nascimento (2011, p. 103), são três as funções dos 
modalizadores em notícias de PC: 1) apontam o grau de validade das proposições; 2) protegem os jornalistas (e pesquisadores) de possíveis críticas ao conteúdo do discurso; 3) criam uma "atmosfera" científica nos textos. No entanto, a análise dos expoentes de Modalidade realizada por Nascimento (2011, p. 103-104) corrobora a ideia de que o discurso de representantes da ciência (o pesquisador e o colega) ocupa lugar de autoridade categórica nas notícias enquanto outros pontos de vista são silenciados ou ignorados.

Em suma, embora as notícias de PC sejam, em tese (e na mídia francesa, conforme MOIRAND, 2003; BEACCO et al., 2002), um espaço de coexistência de diferentes vozes, em notícias em português e inglês previamente analisadas por nós, não há espaço para pontos de vista divergentes. $O$ ponto de vista da ciência é enfatizado por meio da predominância das posições enunciativas do pesquisador e do colega como

Engajamento e redução do espaço dialógico no gênero notícia de popularização científica recurso de autoridade. Esses resultados corroboram a ideia de que os recursos intertextuais usados nas notícias do nosso corpus reforçam o poder hegemônico do discurso científico e, como consequência, promovem uma contração do discurso, causando um efeito de monologismo em notícias de PC publicadas no Brasil (MOTTA-ROTH; LOVATO, 2011, p. 252).

Face a essas considerações, entendemos que o detalhamento dos expoentes linguísticos da contração e da expansão do discurso pode promover um maior entendimento e fomentar a discussão sobre as relações intertextuais expressas nos textos e, consequentemente, sobre o discurso da PC e o conceito de ciência que esse discurso reflete e reforça. Na próxima seção, descrevemos o enquadramento teórico que nos possibilita analisar o discurso de PC e identificar os expoentes linguísticos que caracterizam esse discurso.

\subsection{Linguística Sistêmico-Funcional}

Sob a perspectiva da Linguística Sistêmico-Funcional (LSF), a linguagem é considerada um sistema sociossemiótico multifuncional, pois articula os diferentes significados compartilhados em uma cultura, realizando diferentes funções ${ }^{1}$ (HALLIDAY; HASAN, 1989, p. 4). Tais significados podem ser analisados, em um texto, segundo três metafunções da linguagem: ideacional, interpessoal e textual. A metafunção ideacional, em seu Sistema de Transitividade, realiza o conteúdo proposicional do

1. Halliday e Hasan (1989, p. 15) identificam função como sinônimo de uso, "a maneira como as pessoas usam sua(s) língua(s)”, e a consideram “uma propriedade fundamental da linguagem” (p. 17). 
texto, possibilitando, ao sujeito, representar as experiências do mundo interior e exterior - é o campo do discurso. A metafunção interpessoal, por sua vez, diz respeito ao estabelecimento de relações humanas, ao "processo de interação social" e ao "modo de agir" no mundo social (HALLIDAY; HASAN, 1989, p. 20) - são as relações do discurso. A metafunção textual diz respeito ao papel do texto e às relações internas a

Anelise

Scotti Scherer

Désirée

Motta-Roth este como unidade semântica - é o modo do discurso.

Além de articular os significados compartilhados em uma cultura e de ser multifuncional, a linguagem, nessa perspectiva, segue o princípio da estratificação, que tem função de inter-relacionar o texto, as significações e o contexto (MEURER, 2006, p. 167). Conforme explica Meurer (2006), a linguagem, na ótica sistêmico-funcional, é conceituada como um "sistema semiótico complexo que contém vários níveis" (HALLIDAY; MATTHIESSEN, 2004, p. 24). Essa estratificação, representada na Figura 1, contribui para a sistematização da pesquisa sobre gêneros discursivos no sentido de que, a partir desses níveis (estratos), podemos analisar a linguagem em uso em determinada situação, tanto em seus aspectos formais quanto em seus aspectos funcionais.

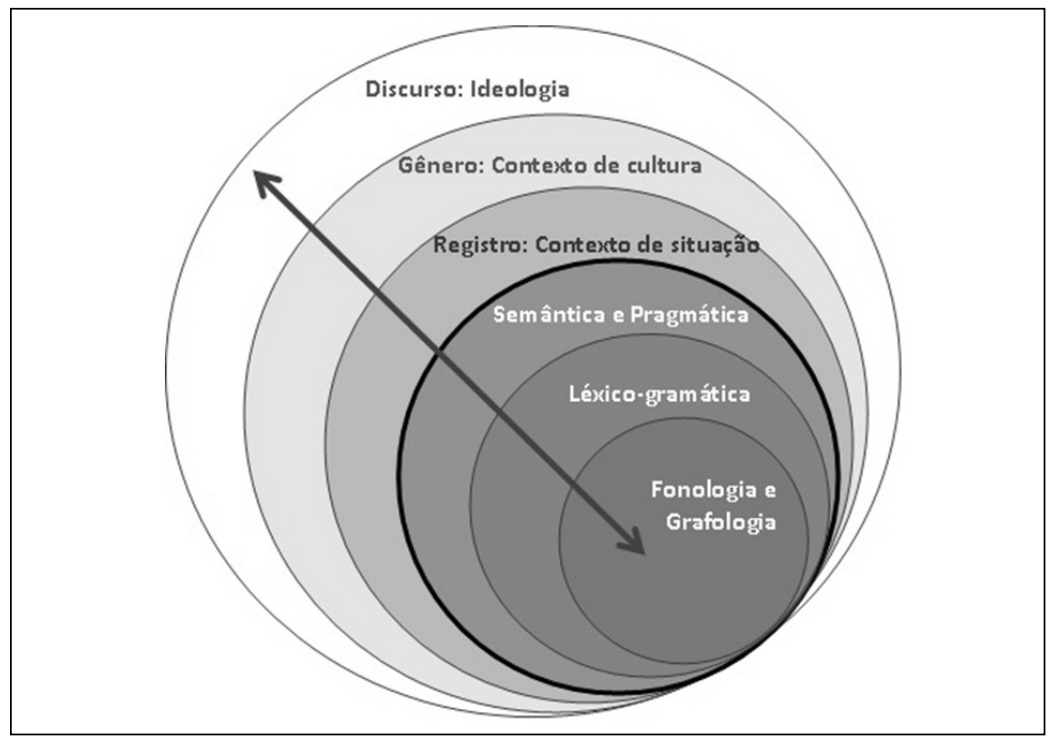

Figura 1 - Estratificação dos planos comunicativos (MOTTA-ROTH, 2008, p. 352)

\footnotetext{
2. A representação visual da estratificação dos planos comunicativos tal como aparece aqui foi proposta por Motta-Roth (2008, p. 352) com o propósito de ilustrar o "[d]esenvolvimento cronológico dos estudos de gênero em relação à estratificação dos planos comunicativos da linguagem (linguístico e contextual)". Essa representação reorganiza as representações de Martin (1992, p. 496) e Hendges (2005, p. 6), demarcando o nível do discurso em correspondência com a ideologia.
} 
Na Figura 1,

c[C]ada círculo concêntrico recontextualiza os círculos menores e assim subsequentemente (cf.: Martin 1992:496), à medida que $a$ análise passa a enfocar unidades cada vez maiores, da fonologia ao discurso. A linha mais espessa demarca o contexto que circunscreve os planos da fonologia, da gramática e da semântica. Nessa representação, gênero é uma conformação de significados recorrentes, organizada em estágios e orientada para o objetivo de realizar práticas sociais (cf.: Martin 2002: 269). Essa conformação é específica da cultura (cf.: Halliday 1978: 145), portanto é uma unidade mais ampla do que o texto [...] e menos abrangente do que discurso. (MOTTA-ROTH, 2008, p. 353).

Engajamento

e redução do espaço dialógico no gênero notícia de popularização científica

Assim, o princípio da estratificação, na LSF, permite que entendamos cada um dos níveis da linguagem como a realização mais concreta ou mais abstrata do nível subsequente, dependendo da direção descendente ou ascendente seguida pela seta. Na Figura 1, a linha mais espessa sinaliza os limites entre texto e contexto, ressaltando a intermediação, do nível da Semântica e Pragmática, como pertinente àqueles significados além da oração, no texto.

Halliday (1994) e Halliday e Matthiessen (2004) dedicam-se a explicar o funcionamento da lexicogramática e as três metafunções da linguagem: ideacional, interpessoal e textual, dando especial atenção ao Sistema de Transitividade. Posteriormente Martin e White (2005) detalham o que chamam de semântica do discurso, concentrando-se no Sistema de Avaliatividade (centrado na metafunção interpessoal), sistema considerado para a análise intertextual empreendida no presente estudo.

Para discutirmos o processo de intertextualidade, portanto, abordaremos: a) as orações verbais (seção 1.2.1) no SIstema de Transitividade, por meio das quais localizamos o discurso relatado ou citado (as projeções) nos textos; b) a modalização (seção 1.2.2) no Sistema de Modalidade por meio do qual os diferentes graus de assertividade das vozes tensionam-se entre si; 3) o subsistema de engajamento (seção 1.2.3), no caso do Sistema da Avaliatividade, que prevê expoentes linguísticos marcadores do grau de posicionamento do jornalista em relação ao discurso do outro. 


\subsubsection{As orações verbais}

Neste estudo, enfocamos as projeções (citação e relato), como estratégias intertextuais usadas pelo autor para inserir o discurso do outro nos textos. A citação e o relato são realizados por orações verbais prototípicas e não prototípicas no texto. Halliday e Matthiessen (2004) usam os termos citação e relato para se referir, respectivamente, a discurso diAnelise reto e discurso indireto na gramática tradicional. Na citação, a voz auScotti Scherer

Désirée toral cita o discurso exatamente como o outro o proferiu originalmente e, no relato, o discurso do outro é interpretado nas palavras do autor.

Motta-Roth

As orações verbais ou orações do dizer (cf. HALLIDAY; MATTHIESSEN, 2004, p. 252), são representadas prototipicamente por $X$ (Dizente) diz (processo verbal) $Y$ (Verbiagem), podendo ainda ser realizada por uma oração com projeção, como $X$ diz (oração projetante) que $Y$ (oração projetada). Além do Dizente (participante obrigatório) e da Verbiagem, podem aparecer o Alvo (participante que recebe a ação verbal - X acusa/elogia $W$ de/como $Y$ ) e o Receptor (participante ao qual o processo verbal é direcionado - X conta a $Z$ que $Y$ ). As orações do dizer realizam-se por uma variedade de verbos como contar, sussurrar, interromper, protestar, etc. Para Halliday (1994, p. 252), em inglês, além do exemplar prototípico say, há verbos específicos para declarações e perguntas (ask, proclaim), verbos cujo sentido combina say com algum elemento circunstancial (answer=say in response, interrupt=say out of turn, protest=say in reservation) e verbos com conotações de diversos tipos (shout, murmur, complain).

Quando o processo verbal projeta outra oração, são duas as possibilidades: citação ( $X$ diz " $Y$ ") ou relato ( $X$ diz que Y). Halliday e Matthiessen $\left(2004\right.$, p. 454) associam a citação a construções paratáticas ${ }^{3}$ do dizer, e o relato, a construções hipotáticas ${ }^{4}$ do dizer/pensar/sentir. 0 Exemplo 1 foi retirado do corpus para ilustrar essa diferença.

Exemplo 1:

Chevalier says that the team was lucky to catch the supernovain the act, and Soderberg agrees: "I definitely won the astronomical lottery". (Nat\#7)

\footnotetext{
3. Parataxe refere-se à relação entre dois elementos (ou orações) de mesmo status, na qual um constitui o início e o outro a continuação (HALLIDAY; MATTHIESSEN, 2004, p. 374). Essa relação é também conhecida como coordenação na gramática tradicional.

4. Hipotaxe refere-se à combinação entre dois elementos de status diferentes, na qual um elemento é dominante e o outro é dependente (HALLIDAY; MATTHIESSEN, 2004, p. 374). Essa relação é também conhecida como subordinação na gramática tradicional.
} 
No complexo oracional Chevalier says that the team was lucky to catch the supernovain the act, há, entre as orações, uma relação hipotática, por meio da qual o discurso de Chevalier (sublinhado) é reportado nas palavras do jornalista sinalizado pela conjunção subordinativa (that). Já em Soderberg agrees: "I definitely won the astronomical lottery", o discurso de Soderberg é citado (nas palavras em que foi proferido) pelo jornalista, por meio de uma relação paratática, e sinalizado por marcas gráficas (dois pontos e aspas).

O Quadro 1 indica as categorias de análise referentes às orações verbais. No discurso jornalístico, as orações verbais possibilitam que o jornalista atribua a informação a fontes, incluindo oficiais, especialistas e testemunhas (HALLIDAY; MATTHIESSEN, 2004, p. 253). Igualmente, no discurso acadêmico, as orações verbais permitem aos autores citar e relatar outros pesquisadores ao mesmo tempo em que se posicionam a partir da escolha do verbo (p. ex. apontar, sugerir, defender).

Em notícias de PC, portanto, o jornalista lança mão da citação e do relato para reportar, aos leitores não especialistas, as recentes descobertas do mundo da ciência (MOTTA-ROTH et al., 2008), buscando credibilidade nas vozes de especialistas autores da pesquisa, outros especialistas, representantes do governo e de outros setores da sociedade (NASCIMENTO, 2011; MARCUZZO, 2011).

\begin{tabular}{|c|c|c|}
\hline \multicolumn{2}{|c|}{ CATEGORIA } & EXEMPLO \\
\hline \multirow[t]{2}{*}{ Semântica } & citação & $\begin{array}{l}\text { The research, partly funded by the US Department of } \\
\text { Defence identified } 23 \text { compounds that were "equiva- } \\
\text { lent to or better than DEET in duration of protection". } \\
\text { "Astonishingly, a number of these protected more than } \\
\text { three times as long as DEET," the paper says. (ABC\#1) }\end{array}$ \\
\hline & relato & $\begin{array}{l}\text { UK scientists found one of the genes increased risk in } \\
\text { people of European descent, but not Japanese people, } \\
\text { reports the journal Nature Genetics. (BBC\#5) }\end{array}$ \\
\hline \multirow{2}{*}{$\begin{array}{c}\text { Lexicogra- } \\
\text { matical }\end{array}$} & $\begin{array}{l}\text { Partici } \\
\text { pante: } \\
\text { Dizente }\end{array}$ & $\begin{array}{l}\text { The current results are promising, says Robert Swift, } \\
\text { a researcher at the Center for Alcohol and Addiction } \\
\text { Studies at Brown University in Rhode Island. "This pa- } \\
\text { per really suggests that gabapentin may be efficacious } \\
\text { in reducing drinking [in alcoholics]," he says. (NAT\#9) }\end{array}$ \\
\hline & $\begin{array}{l}\text { pro- } \\
\text { cesso } \\
\text { verbal }\end{array}$ & $\begin{array}{l}\text { "It would be good to have more effective repellents } \\
\text { that protect against a greater number of insect } \\
\text { species," says Dr Ulrich Bernier, a research chemist } \\
\text { with the Mosquito and Fly Research Unit of the US } \\
\text { Department of Agriculture (USDA) who worked on the } \\
\text { project. (ABC\#1) }\end{array}$ \\
\hline
\end{tabular}

Quadro 1 - Categorias referentes às orações verbais 
Nesse sentido, a citação e o relato são marcas explícitas da intertextualidade ao sinalizar a interação entre diferentes vozes externas e a voz autoral. Por essa razão, na análise do texto, partimos da identificação dos casos de projeção (citação e relato). Essa demarcação de diferentes vozes nos textos de PC indicam a intertextualidade e o processo de recontextualização do discurso científico.

Anelise

Scotti Scherer

\subsubsection{A modalização}

Os estudos da linguagem, sob o ponto de vista da metafunção interpes-

Désirée soal, partem do pressuposto de que a linguagem é usada no mundo "não Motta-Roth apenas para dizer coisas, mas para fazer algo" (GEE, 2011, p. ix). Além de representar as coisas do mundo (metafunção ideacional) em um todo organizado, coeso e coerente (metafunção textual), relacionamo-nos e nos posicionamos uns em relação aos outros ao usar a linguagem (metafunção interpessoal).

Para que possam estabelecer relações e posicionamento/papéis sociais, as pessoas lançam mão de escolhas linguísticas específicas, como as pertencentes aos Sistemas de Polaridade e Modalidade. A Polaridade consiste na oposição entre proposições ou propostas positivas e negativas (sim e não) enquanto a Modalidade consiste no julgamento de quem fala/escreve ou no apelo deste ao julgamento do ouvinte/leitor em relação àquilo que é dito/escrito (HALLIDAY; MATTHIESSEN, 2004, p. 143). Nesse sentido, a Modalidade oferece uma gama de escolhas que transitam entre os dois polos da Polaridade.

Para Halliday e Matthiessen (2004), se a Modalidade for expressa em proposições, prototipicamente realizadas pelo modo indicativo, o discurso mobiliza a categoria de modalização em termos de probabilidade ou de usualidade. No entanto, se a Modalidade for expressa por meio de propostas, prototipicamente realizadas pelo modo imperativo, o discurso mobiliza a modulação em termos de obrigação ou inclinação. Dentre os dois tipos de Modalidade, o que pode aparecer com maior recorrência em notícias de PC é a modalização, uma vez que seus participantes predominantemente negociam informações (proposições) - em vez de bens e serviços (propostas) - sobre descobertas científicas (NASCIMENTO, 2011). Por essa razão, nos deteremos a descrever as categorias de modalização. A Figura 2 representa os graus da modalização em relação aos polos positivo e negativo na forma de uma pilha. 
As escolhas linguísticas da modalização podem variar entre operadores modais finitos (tais como pode e deve), adjuntos modais (como possivelmente e certamente) e metáforas gramaticais interpessoais (MGI) (como eu sei que e eu acho que), indicando graus de probabilidade ou usualidade. Esses graus variam conforme o valor atribuído à Modalidade (HALLIDAY; MATTHIESSEN, 2004, p. 620). Se uma proposição indicar que algo é possível ou que às vezes acontece, mais próxima ao polo negativo estará e, portanto, terá valor modal baixo (pode $(\mathrm{m})$; é capaz de; possivelmente; às vezes). Se a proposição indicar que algo é provável ou que geralmente acontece, estará exatamente entre os dois polos e terá valor modal médio. Já, se uma proposição indicar que algo é certo ou que sempre acontece, estará mais próxima do polo positivo e terá valor modal alto.

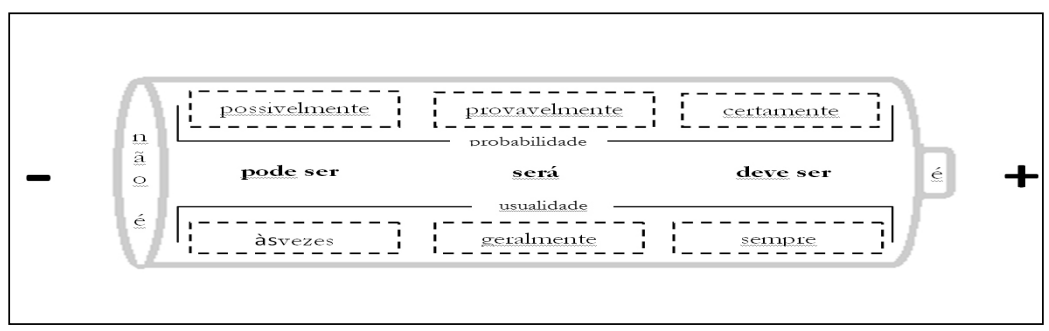

Figura 2 - Relação entre Polaridade e modalização (adaptado de HALLIDAY; MATTHIESSEN, 2004, p. 619)

Os expoentes linguísticos da modalização são pertinentes à análise textual do presente estudo na medida em que sinalizam o alinhamento do jornalista com a proposição em questão, demarcando o seu ponto de vista em relação às outras vozes mobilizadas no texto. Neste estudo, enfatizamos as marcas de probabilidade por serem marcas do processo de recontextualização da ciência na mídia de massa. Essas três categorias léxico-gramaticais da modalização também são responsáveis por realizar as categorias semânticas de acolhimento e atribuição da expansão dialógica do subsistema de engajamento, na perspectiva da Avaliatividade (MARTIN; WHITE, 2005), conforme explicamos na próxima seção.

\subsubsection{O subsistema de engajamento}

Juntamente com os subsistemas de atitude e de gradação, o subsistema do engajamento é parte do Sistema de Avaliatividade, proposto por Martin e White (2005), e destina-se principalmente às relações entre a voz autoral e a(s) voz(es) externa(s) ao texto, as possíveis posições alternativas e o leitor 
potencial. Por enfatizar as questões axiológicas da linguagem em uso, Martin e White (2005) localizam o Sistema da Avaliatividade, ao mesmo tempo, na semântica do discurso e na metafunção interpessoal.

Encontramos, na base do Sistema de Avaliatividade e, consequentemente, do subsistema de engajamento, o pressuposto bakhtiniano de que todo texto "dialoga" com outros textos produzidos e consumidos

Anelise no passado e, também, suscita um diálogo com textos que serão proScotti Scherer Désirée uma dimensão axiológica no texto. Para Faraco (2009, p. 47), na obra Motta-Roth duzidos e consumidos no futuro, ocupando, assim, um lugar específico em uma cadeia dinâmica de textos. Esse pressuposto implica, também, de Bakhtin, "a significação dos enunciados tem sempre uma dimensão avaliativa, expressa sempre um posicionamento social valorativo".

Martin e White (2005, p. 93) partem desse pressuposto ao formular o arcabouço teórico do engajamento, o qual: a) fornece uma sistematização da realização linguística dos posicionamentos nos textos; b) possibilita a caracterização do estilo interpessoal do autor e de suas estratégias retóricas com base nos tipos de cenários heteroglóssicos construídos nos textos e na maneira como eles se engajam com esse cenário; c) refere-se aos significados no contexto e aos efeitos retóricos em vez das formas gramaticais.

O subsistema de engajamento fornece, portanto, categorias de análise pertinentes ao estudo da intertextualidade em notícias de PC, uma vez que esses textos são constituídos, principalmente, por meio de uma multiplicidade de vozes além da voz autoral e na relação que o autor estabelece com e entre elas.

Uma primeira distinção feita por Martin e White (2005), nesse subsistema, é entre monoglossia e heteroglossia. Eles partem das noções bakhtinianas de dialogismo e heteroglossia, sob as quais, toda comunicação verbal é dialógica no sentido de que, ao falarmos ou escrevermos, sempre revelamos a influência de, referimo-nos a ou retomamos de alguma forma o que já foi dito/escrito antes e simultaneamente antecipamos a resposta de interlocutores potenciais, reais ou imaginários ( $p$. 92). Os autores consideram (p. 102) que a heteroglossia aponta para a capacidade de um texto recrutar/admitir e articular, em maior ou menor grau, pontos de vista alternativos (vozes) à da voz autoral.

Martin e White (2005, p. 99) defendem que todo enunciado é essencialmente dialógico, no entanto argumentam que se pode restringir o espaço dialógico por meio de afirmações categóricas, que suprimem 
ou silenciam outras vozes alternativas, enfatizando um ponto de vista como o melhor ou o único, em vez de expressar uma posição como simplesmente uma entre uma gama de possibilidades. A esses enunciados categóricos, Martin e White chamam, em termos bakhtinianos, de "monoglóssicos" ou "indialogados" (undialogised) (p. 99).

Em que pese a multiplicidade de vozes ser marca do conceito bakhtiniano de polifonia, neste estudo, entendemos que a heteroglossia, conforme a definição de Martin e White (2005), difere do conceito de polifonia no que diz respeito ao estabelecimento de uma "tensão entre as vozes", "um conflito de consciências, valores, identidade/alteridade" (BRAIT, 2009, p. 66-67). Consideramos que o conceito de polifonia está relacionado ao estabelecimento de um debate propriamente dito, em que as vozes (posições sociais) mobilizadas não somente se "encontram" em um texto, mas também se "confrontam" a partir de pontos de vista diferentes/conflitantes (FARACO, 2009, p. 64-67).

Uma segunda distinção corresponde às categorias heteroglóssicas de expansão e de contração do discurso (MARTIN; WHITE, 2005, p. 103), a partir das quais a voz autoral amplia as fronteiras do texto, permitindo que outras vozes interajam com a sua, ou delimita as fronteiras do texto de modo a ignorar ou refutar a interação de diferentes vozes. Encaradas como movimentos em direções opostas encontrados em um dado texto, a contração e a expansão dialógica constituem um jogo de forças relativamente instável. Quando, nesse jogo de forças, as forças centrípetas (de contração) predominam (como no caso de notícias de PC), o resultado é o efeito de monologismo, "um intertexto monologal entre atores sociais que representam o ponto de vista da ciência" (MOTTA-ROTH; LOVATO, 2011, p. 262, citando MOIRAND, 2003).

Para que possamos identificar as marcas linguísticas das categorias gerais de contração e expansão dialógicas (e consequentemente, do jogo de forças instaurado por elas), Martin e White (2005) propõem quatro subcategorias: 1) refutação e 2) ratificação, no caso da contração dialógica; e 3) acolhimento e 4) atribuição, no caso da expansão dialógica, conforme Figura 3. 
Anelise
Scotti Scherer

Désirée

Motta-Roth

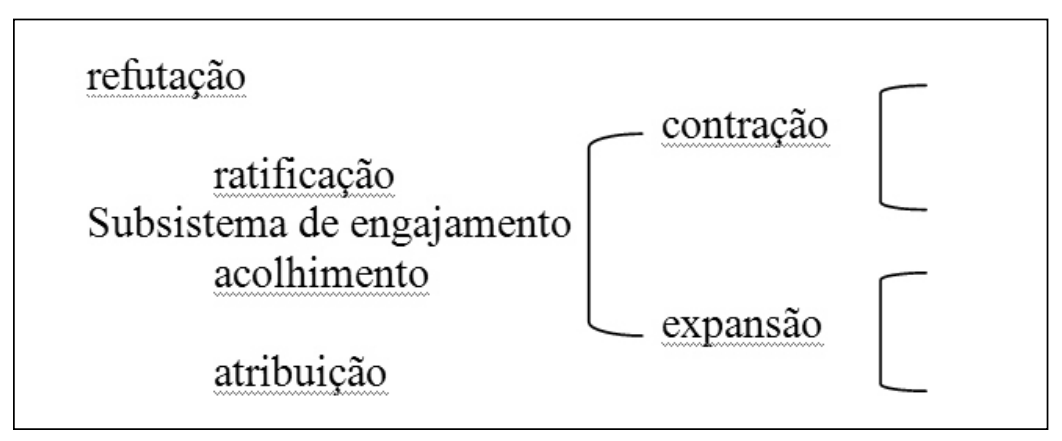

Figura 3 - Contração e expansão dialógica no subsistema de engajamento

A essas quatro subcategorias são atribuídas outras nove subdivisões. No caso da contração dialógica por refutação, temos a) negação d) pronunciamento e e) endosso. No caso da expansão dialógica por acolhimento, temos f) probabilidade e g) evidência, enquanto que por atribuição, temos h) reconhecimento e i) distanciamento (Quadro 2). 


\begin{tabular}{|c|c|c|c|c|}
\hline \multicolumn{5}{|c|}{ Subsistema de engajamento } \\
\hline & Categorias & \multicolumn{2}{|c|}{ Subcategorias contrativas e expansivas } & \multirow{2}{*}{$\begin{array}{l}\text { Exp. linguísticos } \\
\text { don't; not; no; nothing; not the case; não; } \\
\text { nem; nunca; jamais }\end{array}$} \\
\hline \multirow{9}{*}{$\begin{array}{l}\text { Heteroglossia } \\
\text { Refere-se a to- } \\
\text { das as locuções } \\
\text { que funcionam } \\
\text { de forma a } \\
\text { reconhecer } \\
\text { que o pano de } \\
\text { fundo do texto é } \\
\text { diverso (abriga } \\
\text { diversas posi- } \\
\text { ções possíveis) } \\
\text { (p. 99) } \\
\text { Enunciados } \\
\text { heteroglóssicos } \\
\text { são classificados } \\
\text { de acordo com } \\
\text { o grau em } \\
\text { que, por meio } \\
\text { de uma ou } \\
\text { mais locuções } \\
\text { heteroglóssicas, } \\
\text { ativamente } \\
\text { permitem a } \\
\text { coexistência de } \\
\text { vozes e posições } \\
\text { alternativas } \\
\text { dialógicas } \\
\text { (Expansão Dia- } \\
\text { lógica) ou } \\
\text { agem de modo } \\
\text { a desafiá-las, } \\
\text { rechaçá-las ou } \\
\text { restringir seu } \\
\text { alcance (Contra- } \\
\text { ção Dialógica) } \\
\text { (p. 102) }\end{array}$} & \multirow{5}{*}{$\begin{array}{l}\text { Contração } \\
\text { Dialógica (a) } \\
\text { Formulações } \\
\text { em que o } \\
\text { espaço para } \\
\text { alternativas } \\
\text { dialógicas é res- } \\
\text { trito, contraído, } \\
\text { privilegiando } \\
\text { uma posição. }\end{array}$} & \multirow{2}{*}{$\begin{array}{l}\text { Refutação } \\
\text { Casos em que a voz } \\
\text { autoral posiciona- } \\
\text {-se contraiamente } \\
\text { ou rejeita alguma } \\
\text { posição contrária a } \\
\text { sua (p. } 97)\end{array}$} & \begin{tabular}{|l|} 
Negação \\
Recurso que introduz uma posição al- \\
ternativa afirmativa (pressuposição) \\
no diálogo, reconhecendo-a para, \\
então, negá-la, rejeitá-la (p.118). \\
\end{tabular} & \\
\hline & & & \begin{tabular}{|l|} 
Contestaçãa \\
Formulações que representam a \\
proposição como substituindo ou \\
superando e, portando, contestando \\
uma outra proposição que seria \\
esperada em seu lugar (p.120). \\
\end{tabular} & $\begin{array}{l}\text { although; even though; however; yet; but; } \\
\text { surprisingly; amazingly; even; only; just; } \\
\text { still; apesar de; embora; entretanto; mas; } \\
\text { surpreendentemente; mesmo; apenas; } \\
\text { somente; ainda }\end{array}$ \\
\hline & & \multirow{3}{*}{$\begin{array}{l}\text { Ratificação } \\
\text { Casos em que a voz } \\
\text { autoral, por meio } \\
\text { de interpolação, } \\
\text { ênfase ou inter- } \\
\text { venção, apresenta } \\
\text { a proposição como } \\
\text { altamente válida e } \\
\text { confiável, fazendo } \\
\text { com que posições } \\
\text { alternativas sejam } \\
\text { confrontadas ou } \\
\text { mesmo excluídas, } \\
\text { limitando o espaço } \\
\text { de diálogo entre } \\
\text { posições alternati- } \\
\text { vas (p. 98; } 118 \text { ) }\end{array}$} & \begin{tabular}{|l|} 
Concordância \\
Formulações que explicitamente \\
posicionam o leitor/ouvinte em \\
concordância com a voz autoral, \\
projetando-o como alguém que com- \\
partilha da mesma posição dialógica \\
que o autor (p. 122). \\
\end{tabular} & $\begin{array}{l}\text { naturally; of course; obviously; admitte- } \\
\text { dly; not surprisingly; certainly; yes; sure; } \\
\text { certamente/com certeza; seguramente; } \\
\text { naturalmente }\end{array}$ \\
\hline & & & \begin{tabular}{|l|} 
Pronunciamento \\
Formulações nas quais a voz autoral \\
faz uso de ênfases, intervenções ou \\
interpolações explícitas com a fina- \\
lidade de insistir, garantir a validade \\
da proposição como resposta a uma \\
posição contrária defendida pelo \\
interlocutor ou por uma terceira \\
pessoa (p. 127-130). \\
\end{tabular} & $\begin{array}{l}\text { I contend; the truth of the matter is; } \\
\text { there can be no doubt that; the facts of } \\
\text { the matter are that; we can only conclude } \\
\text { that; we have to remember that; you } \\
\text { must agree that; really; indeed; it's abso- } \\
\text { lutely clear to me that; a verdade é que; } \\
\text { eu defendo que; só podemos concluir que; } \\
\text { temos que concordar que; na verdade; de } \\
\text { fato; entonação (oral) }\end{array}$ \\
\hline & & & \begin{tabular}{|l} 
Endosso \\
Formulações em que a voz autoral \\
apresenta a proposição como válida, \\
verdadeira, alinhando sua posição \\
com a posição da voz externa/fonte \\
da proposição. Esse alinhamento \\
é marcado por meio de processos \\
verbais/mentais que permitem à \\
voz autoral marcar uma posição \\
particular em relação à proposição \\
atribuída, representando-a como \\
verdadeira, válida (p. 103)
\end{tabular} & $\begin{array}{l}X \text { has demonstrated that; As } X \text { has } \\
\text { shown; } X \text { shows; } X \text { demonstrates; show; } \\
\text { prove; demonstrate; find; point out; } \\
\text { mostrar; demonstrar/demonstração; } \\
\text { provar; descobrir/ descoberta; apontar; } \\
\text { concluir }\end{array}$ \\
\hline & \multirow{4}{*}{$\begin{array}{l}\text { Expansão } \\
\text { Dialógica (b) } \\
\text { Formulações } \\
\text { em que o espaço } \\
\text { para alternati- } \\
\text { vas dialógicas } \\
\text { é ampliado, } \\
\text { expandido, } \\
\text { promovendo } \\
\text { a coexistência } \\
\text { de posições } \\
\text { alternativas. }\end{array}$} & \multirow{2}{*}{$\begin{array}{l}\text { Acolhimento } \\
\text { Casos em que a voz } \\
\text { autoral representa } \\
\text { a proposição como } \\
\text { uma dentre uma } \\
\text { gama de posições } \\
\text { possíveis ao } \\
\text { apresentá-la } \\
\text { fundamentada } \\
\text { em sua própria } \\
\text { contingência (p. } \\
\text { 98), ampliando em } \\
\text { maior ou menor } \\
\text { grau o espaço para } \\
\text { possibilidades dia- } \\
\text { lógicas (p. 104) }\end{array}$} & $\begin{array}{l}\text { Probabilidade } \\
\text { Formulações em que a voz autoral } \\
\text { acolhe posições alternativas a sua } \\
\text { (ao mesmo tempo em que marca sua } \\
\text { subjetividade) ao avaliar a proposição } \\
\text { como mais ou menos plausível ou } \\
\text { duvidosa (provável ou possível) (p. } \\
\text { 104-105). }\end{array}$ & $\begin{array}{l}\text { perhaps; possibily; probably; maybe; } \\
\text { this may be; definitely; it's probable } \\
\text { that; it's possible that; it's likely that; in } \\
\text { my view; I suspect that; I believe that; } \\
\text { I think that; it's almost certain that; } \\
\text { I'm convinced that; I doubt that; may/ } \\
\text { might/could/will/must; pode originar; } \\
\text { pode exigir; provavelmente; talvez; } \text { em } \\
\text { meu ponto de vista; eu acho que,eu estou } \\
\text { convencido que }\end{array}$ \\
\hline & & & \begin{tabular}{|l|} 
Evidência \\
Formulações em que a voz autoral \\
acolhe posiçôes alternativas a sua \\
(ao mesmo tempo em que marca sua \\
subjetividade) ao avaliar a proposição \\
como mais ou menos plausível ou \\
duvidosa (provável ou possível), \\
tomando por base aspectos de evi- \\
dências/aparência (p. 104-105). \\
\end{tabular} & $\begin{array}{l}\text { it seems; it appears; the evidence/beha- } \\
\text { viour suggests; the research suggests } \\
\text { apparently; hear }\end{array}$ \\
\hline & & \multirow{2}{*}{$\begin{array}{l}\text { Atribuição } \\
\text { Casos em que a voz } \\
\text { autoral representa } \\
\text { a proposição como } \\
\text { uma dentre uma } \\
\text { gama de posições } \\
\text { possíveis ao } \\
\text { apresentá-la } \\
\text { fundamentada na } \\
\text { subjetividade de } \\
\text { uma voz externa ao } \\
\text { texto, invocando } \\
\text { tais alternativas } \\
\text { dialógicas (p. 98). } \\
\text { Há, nesse processo, } \\
\text { uma dissociação } \\
\text { entre a voz autoral } \\
\text { e a proposição, } \\
\text { atribuída a uma } \\
\text { voz externa (p. } \\
\text { 111). }\end{array}$} & \begin{tabular}{|l} 
Reconhecimento \\
Formulações em que não há indica- \\
ção explícita da posição da voz auto- \\
ral em relação à proposição (discurso \\
do outro) (p.112). O reconhecimento \\
é marcado por meio de processos \\
verbais/mentais ditos "neutros" por \\
não marcarem a posição particular \\
(axiológica) da voz autoral em rela- \\
ção à proposição atribuída. \\
\end{tabular} & $\begin{array}{l}X \text { said; } X \text { believes; according to } X ; \text { in } X \\
\text { view; } X \text { 's assertion that; } X \text { 's belief that; } \\
\text { hearsay (reportedly; it is said that); } X \\
\text { describes; arguing that, } X \text { demanded } \\
\text { that;say; report; state; declare; announce; } \\
\text { believe; think; relatar; declarar; de } \\
\text { acordo com; segundo } x \text {; acreditar; crer; } \\
\text { declaração; na visão de }\end{array}$ \\
\hline & & & $\begin{array}{l}\text { Distanciamento } \\
\text { Formulações em que a voz autoral } \\
\text { não assume responsabilidade sobre } \\
\text { a proposição, explicitamente distan- } \\
\text { ciando-se da posição da voz externa/ } \\
\text { fonte da proposição (p. 103), podendo } \\
\text { inclusive apresentar a proposição } \\
\text { atribuída como duvidosa ou suscetí- } \\
\text { vel à discussão. Esse distanciamento } \\
\text { é marcado por meio de processos } \\
\text { verbais/mentais que permitem à voz } \\
\text { autoral marcar uma posição particu- } \\
\text { lar em relação à proposição atribuída, } \\
\text { representando-a como duvidosa e } \\
\text { suscetível à discussão. } \\
\end{array}$ & $\begin{array}{l}\text { X claims that; it's rumoured that } \\
\text { (hearsay); reivindicar; alegar; sugerir; } \\
\text { garantir; aspas; explicar; argumentar; } \\
\text { suspeitar; reivindicar; alegar; garantir }\end{array}$ \\
\hline
\end{tabular}

Engajamento

e redução do

espaço dialógico

no gênero notícia

de popularização

científica

277

Quadro 2 - Expoentes linguísticos do subsistema de engajamento (cf. MARTIN; WHITE, 2005; VIAN JR, 2010; MOTTA-ROTH; LOVATO, 2011) 
O Quadro 2 mostra recursos e expoentes linguísticos das categorias heteroglóssicas do subsistema de engajamento que servem de base para a identificação das realizações linguísticas do subsistema de engajamento e, portanto, de contração e expansão nas notícias de PC que compõem o corpus deste estudo.

Dentre esses recursos heteroglóssicos, ressaltamos três como Anelise foco deste estudo por estarem associados a projeções (citação e relato): Scotti Scherer

Désirée atribuição por reconhecimento. Grosso modo, podemos dizer sobre esMotta-Roth no caso da contração dialógica, destacamos ratificação por endosso; no caso da expansão dialógica, destacamos atribuição por distanciamento e sas categorias que, ao aderir a uma proposição de forma assertiva ( $r a-$ tificação), o autor pode escolher alinhar o seu discurso ao discurso de uma voz externa (endosso). Já, ao atribuir o discurso a uma voz externa (atribuição), o autor pode escolher entre não explicitar sua posição em relação ao discurso do outro (reconhecimento) ou indicar o seu distanciamento em relação ao discurso alheio.

A partir da categoria de endosso, a voz autoral promove a limitação da participação de posições alternativas na interação por meio da representação de determinada posição, como sendo correta, inegável, altamente válida, como em Estudos provam que atividades físicas fazem bem à saúde (MARTIN; WHITE, 2005, p. 121-128).

Por outro lado, o recurso de atribuição permite que o autor credite o discurso a diferentes vozes externas ao texto, como em Construtora Delta poderá ser excluida das obras do PAC, diz ministra (reconhecimento); ou descomprometendo-se com o que é dito, como em 0 réu alega ser inocente (distanciamento). Ao fazer isso, o autor "representa a proposição como uma em um leque de posições possíveis" (MARTIN; WHITE, 2005, p. 98).

Segundo Martin e White (2005, p. 96), a partir de uma análise dos significados do engajamento, é possível identificar o posicionamento dialógico particular associado a determinado significado e descrever o que está em jogo quando um significado é escolhido em detrimento de outro. Entendemos, portanto, que identificar o posicionamento dialógico em notícias de PC nos possibilita verificar o grau de abertura ou fechamento do espaço do diálogo entre atores sociais, entre pontos de vista como o da ciência em relação a outras posições enunciativas envolvidas no processo de PC.

A título de encerramento desta seção, ressaltamos nosso entendimento de que, em qualquer evento comunicativo, há uma relação 
dialética constitutiva entre texto e contexto: ao mesmo tempo em que o discurso restringe as escolhas lexicogramaticais, a Lexicogramática concretiza/instancia o discurso. Destacamos também nosso entendimento de que todo caráter mais ou menos dialógico de um texto é determinado pelas condições sócio-históricas de sua produção, distribuição e consumo, conforme o gênero do discurso envolvido. Assumimos a ideia de que a ideologia opera por meio de gêneros que denotam o funcionamento das instituições sociais (VOLOCHINOV, 1995) e que a ferramenta de parcelamento da linguagem fornecida pela LSF nos permite partir de critérios funcionais para identificar os elementos da Lexicogramática relevantes em um dado texto para um dado contexto. Considerando, pois, a relação dialética entre texto e contexto, buscamos descrever acima o contexto recontextualizador da PC, do qual a intertextualidade é

Engajamento e redução do espaço dialógico no gênero notícia de popularização científica característica marcante, especificamente no gênero notícia de PC. Na próxima seção, detalhamos o universo de análise, o corpus, as categorias e os procedimentos metodológicos do presente estudo.

\section{0 percurso metodológico}

As 45 notícias de PC analisadas neste estudo foram publicadas entre janeiro de 2007 e maio de 2009, em três publicações de PC: 1) Scientific American, 2) ABC Science, e 3) Nature News. Elas integram um corpus mais amplo, selecionado a partir dos seguintes critérios (MOTTA-ROTH, 2007):

a) as notícias foram retiradas de publicações escritas em língua inglesa;

b) essas publicações apresentam compromisso explícito em popularizar ciência e/ou educar sobre ciência, dedicada a uma audiência não especializada no assunto da notícia (na declaração de missão da publicação);

c) os textos fazem parte de seções destinadas a notícias sobre ciência e tecnologia;

d) o site da revista mantém dinâmica de atualização diária ou semanal;

e) os textos estão disponíveis gratuitamente na mídia eletrônica on-line;

f) a extensão dos textos deve se aproximar do número médio de palavras dos textos publicados nesses sites. A extensão média de 1046 palavras foi identificada a partir de um levantamento por amostragem, realizado pelos integrantes do GT-LABLER em publicações de PC eletrônicas que atendessem aos critérios a, b, c e d descritos acima. 
As categorias analíticas usadas são, principalmente, os recursos intertextuais de representação do discurso do outro, citação e relato, realizados, na Léxico-gramática, por orações verbais (prototípicas e não prototípicas), conforme explicado na seção 1.2.1. Sob a perspectiva da Avaliatividade, são analisados também os expoentes linguísticos de expansão e contração dialógicas (com base em MARTIN; WHITE, 2005; VIAN JR, 2010;

Anelise MOTTA-ROTH; LOVATO, 2011), com foco nos recursos de atribuição-recoScotti Scherer

Désirée e relato, as categorias processo, participante e circunstância do Sistema da Motta-Roth Transitividade, e os recursos de modalização (principalmente o de probabilidade) do Sistema de Modalidade (HALLIDAY; MATTHIESSEN, 2004). A análise dos expoentes linguísticos compreende os seguintes procedimentos:

a) identificação e interpretação do conteúdo do discurso representado com base na representação esquemática da organização retórica do gênero notícia de PC proposto por Motta-Roth (2009); b) identificação das diferentes vozes representadas nos textos do corpus por referência ao Sistema de Transitividade da LSF. Identificamos ocorrências de citação e relato, por meio da localização das marcas gráficas de representação do discurso (p. ex., aspas) e de projeções por meio de processos verbais e mentais. A identificação das vozes nas notícias parte das cinco posições enunciativas já descritas acima: o pesquisador que desenvolveu a pesquisa noticiada, o colega cientista, cuja opinião é citada, o governo, representado por servidor ou órgão público, o público, representado por não especialista, e o próprio jornalista autor da notícia (ver seção 1.1);

c) identificação e descrição, com auxílio do Sistema de Avaliatividade (mais especificamente do subsistema de engajamento) das marcas linguísticas de contração e expansão do discurso, a partir dos expoentes relativos às vozes externas referidas pelo jornalista (recursos de reconhecimento, distanciamento e endosso); d) interpretação e explicação do engajamento do jornalista em relação às diferentes vozes citadas/relatadas nos textos, com vistas a verificar em que medida e como se dá o efeito de monologismo previamente estudado em trabalhos do GT LABLER.

$\mathrm{Na}$ próxima seção, são apresentados e discutidos os resultados do estudo. 


\section{Marcas do efeito de monologismo nas notícias de PC}

Apresentamos, nesta seção, os resultados da análise do contexto de situação em termos das variáveis contextuais (campo, relações e modo) do gênero notícia de PC (seção 3.1) e da análise do texto, referente aos expoentes linguísticos dos recursos de engajamento atribuição-reconhecimento, atribuição-distanciamento e ratificação-endosso, com ênfase nos dois últimos recursos por explicitarem o posicionamento do jornalista em relação ao discurso representado (seção 3.2).

\subsection{Resultados da análise do contexto}

A análise do contexto de situação das notícias do corpus baseia-se na investigação dos sites das publicações Scientific American, ABC Science e Nature, em termos de: a) campo (atividade realizada), b) relações (papéis e interação entre os participantes) e c) modo (papel e organização da linguagem).

O Campo da notícia de PC diz respeito à atividade de recontextualização do discurso científico no discurso jornalístico, envolvendo a midiatização de resultados de uma pesquisa científica que assume o status de descoberta relevante para a sociedade em geral. Por exemplo, um estudo em microbiologia desenvolvido e divulgado no contexto científico, por pesquisadores da França e dos Estados Unidos é relatado no periódico especializado Science (com acesso restrito/pago) e, posteriormente, popularizado em um dos textos do corpus (ABC\#6). Nesse caso, o contexto científico envolve as atividades realizadas em laboratório, o processo de pesquisa em si, a divulgação do estudo entre especialistas, em artigos, seminários ou reuniões de grupo de pesquisa, para discussão e avanço na produção do conhecimento. Por sua vez, o contexto midiático/recontextualizador envolve a popularização, na publicação $A B C$ Science, do relato dessa pesquisa para o público não especialista em geral, sem restrição de acesso ao conteúdo da notícia e em linguagem que tem por função precípua explicar a ciência. Sinal disso se vê nas porções de texto multimodal das notícias, em que se usam imagens. Em 30 notícias de PC publicadas na BBC News e na Scientific American, “[as] imagens estãomais associadas ao caráter jornalístico do gênero e menos ao seu caráter científico" (MARQUES; MOTTA-ROTH; HENDGES, 2010 ). Em geral, as imagens de notícias de PC têm um referente no "mundo da vida - aquilo que é representado pode ser visto a olho nu, compreendido a partir de um sistema de conhecimento da vida cotidiana, em contraste com imagens, cujo referente se localiza no "mundo da ciência 
- aquilo que é representado pode ser visto apenas por meio de um/a instrumento/ferramenta/tecnologia (p. ex. um microscópio) e compreendido a partir de um sistema de conhecimento perito (ciência)" (MOTTA-ROTH; SOCOLOSKI, 2009). Conforme discutiremos mais adiante, os graus de popularização/cientificidade com que esse discurso é recontextualizado estão mais explicitamente relacionados aos participantes

Anelise Scotti Scherer

Désirée Motta-Roth da interação e suas identidades/papeis sociais.

Nossa análise das Relações em notícias de PC apontou três participantes recorrentes: o jornalista, escritor da notícia; o especialista, envolvido diretamente com o saber científico (pode ou não ser o responsável pela pesquisa); e o leitor. Em pesquisa prévia, foi identificada ainda a existência de vozes, mobilizadas pelo jornalista para promover o debate sobre a pesquisa popularizada, pertencentes a outros setores sociais: técnicos e instituições ligados ao campo da pesquisa (p. ex., profissionais da saúde, quando o texto em questão populariza um estudo sobre câncer cerebral), representantes do governo (p. ex., pesquisadores a trabalho do governo em instituições governamentais) e público (p. ex., grupos de pessoas ou indivíduos que opinam sobre as implicações dos achados científicos para sua vida) (MOTTA-ROTH; LOVATO, 2009; MARCUZZO, 2011). Entretanto, verificamos ocorrências de vozes do público e do governo somente no subcorpus da Scientific American, enquanto que, nos subcorpora da ABC Science e Nature, foram identificados apenas os participantes principais: além do jornalista e do leitor, o especialista (responsável - ou não - pelo estudo).

Os participantes envolvidos na interação relacionam-se de forma hierárquica em relação ao conhecimento científico (MOIRAND, 2003; MYERS, 2003). Nessa hierarquia, maior grau de autoridade é conferido ao cientista responsável pela pesquisa e aos especialistas na área do estudo. O jornalista, em menor grau de autoridade, faz o entremeio entre cientistas e o público em geral (leitores potenciais), ao qual é atribuído grau mínimo de autoridade em razão do distanciamento do contexto científico referente à pesquisa em questão. A partir de entrevista com um dos jornalistas responsáveis pela publicação das notícias de PC do nosso corpus, Marcuzzo (2011, p. 113) sugere que as razões pelas quais especialistas são convidados a falar e o público é silenciado são as mesmas: o grau de acesso ao conhecimento especializado. Quanto maior for o conhecimento sobre o tema da pesquisa popularizada, maior é a autoridade conferida ao participante. A mídia busca o testemunho especializado sem demonstrar interesse em inscrever a voz do público 
nas notícias de PC, embora este seja a sociedade ampla, o consumidor último dos resultados de pesquisa e o financiador da empreitada científica. Nesse sentido, a hierarquia entre os participantes da notícia de PC (Figura 4) é estabelecida segundo o critério autoridade.

Assim, os papéis desempenhados pelos participantes (suas identidades) são definidos em termos de: a) especialistas na área do conhecimento em que o estudo foi realizado em contraste com não especialistas; b) o campo ao qual pertencem, por exemplo, o campo científico em contraste com o campo jornalístico ou mesmo a sociedade em geral. As relações de poder entre esses participantes foram estabelecidas conforme o grau de autoridade nos assuntos da ciência: quanto maior a proximidade do participante em relação ao contexto científico em que a pesquisa foi realizada, maior autoridade (maior poder) é creditada em comparação ao leitor não especialista (menor poder).

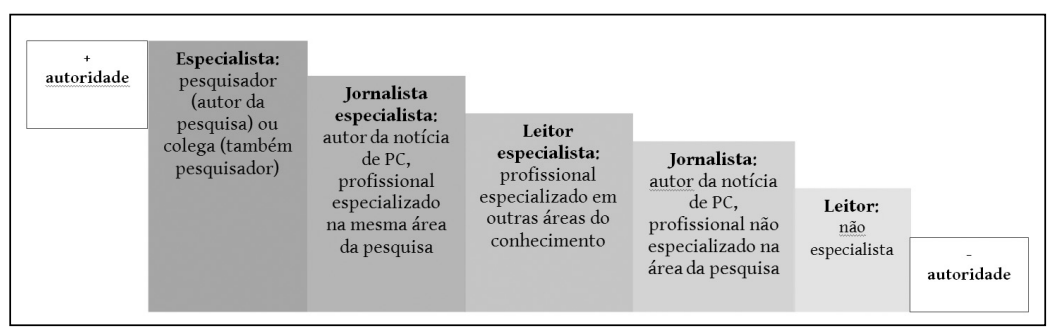

Figura 4 - Relação hierárquica dos participantes da notícia de PC

O Modo relativo ao contexto de publicação das notícias de PC analisadas diz respeito ao canal gráfico, com predomínio da modalidade escrita sobre a visual, e ao meio eletrônico (online), que oferece ao leitor hiperlinks com endereços eletrônicos de outros textos com informações adicionais para expandir o conteúdo da notícia. Embora todos os textos do corpus sejam de natureza verbo-visual, a linguagem verbal se sobrepõe à linguagem visual no que diz respeito à recontextualização do relato da pesquisa. Sob a perspectiva da multimodalidade, o papel das imagens, nessa prática social, é "materializa[r] o objetivo do gênero, que é o de estreitar a relação entre sociedade, linguagem e ciência", uma vez que as imagens têm função de "atrair a atenção do leitor e sintetizar a temática da notícia" (MARQUES; MOTTA-ROTH; HENDGES, 2010). A organização textual dos 45 textos do nosso corpus corrobora esses dados, uma vez que todas as notícias de PC apresentam imagens próximas ao título e ao lide com função de sintetizar a temática da notícia. 
Análises de notícias de PC em português (publicadas na Ciência Hoje On-line) e em inglês (publicadas na BBC News e Scientific American) ${ }^{5}$ indicaram uma organização retórica que, dentre outros aspectos, enfatiza/tematiza os resultados gerais e as conclusões da pesquisa para, então, detalhar outros aspectos (como metodologia, resultados, implicações) (MOTTA-ROTH; LOVATO, 2009; MOTTA-ROTH, 2009). Isso sugeAnelise re que as conclusões da pesquisa e a síntese dos resultados são as informações consideradas mais relevantes ao público em geral. Três outros movimentos são recursivos ao longo dos textos e evidenciam o caráter Désirée intertextual do gênero: "a elaboração de comentários e narrativas", Motta-Roth “explanação de princípios e conceitos" e "ênfase na perspectiva social/ local" (MOTTA-ROTH, 2009, p. 171). Além disso, a linguagem, nesses textos, é permeada por marcas da recontextualização do discurso científico, tais como metáforas (SANTOS, 2010), aposto e glosa (GERHARDT, 2011), modalização (NASCIMENTO, 2011) e projeção (MARCUZZO, 2011; SCHERER, 2013).

Em suma, a análise do contexto da notícia de PC revela uma atividade de popularização de uma pesquisa científica (recontextualização do discurso científico) para a sociedade em geral por meio do contexto recontextualizador da mídia de massa. Estão envolvidos, nessa atividade, o jornalista (autor da notícia de PC), os representantes de diferentes setores da sociedade (as vozes, no texto) e a sociedade em geral (leitores). As relações de poder entre esses participantes dependem da autoridade a eles conferida para se posicionarem sobre os assuntos científicos. A linguagem, principalmente na modalidade verbal/escrita, tem papel constitutivo nesse gênero e enfatiza a relação do discurso científico com a vida cotidiana como forma de captação do leitor não especialista. Na próxima seção, esses aspectos do gênero são investigados em sua materialidade textual, com ênfase nos expoentes linguísticos de engajamento em projeções nos textos do corpus.

\subsection{Resultados da análise do texto}

Nesta seção, apresentamos a análise dos expoentes linguísticos de engajamento, identificados nas ocorrências de representação do discurso alheio (citação e relato), por meio dos quais o jornalista insere vozes externas nas notícias de PC. A partir de uma análise da Transitividade, por

5. Ver nota 7. 
meio da identificação do Dizente da oração, percebemos que, dentre os representantes de diferentes vozes encontradas no corpus, 96\% são de especialistas, autores das pesquisas popularizadas ou colegas - atores sociais ligados ao âmbito da ciência, referidos por elementos lexicais, como a biologist at Pennsylvania State University, granular materials researcher, a molecular neuroscientist at the University of Oxford. Os discursos relatados/citados referem-se quase que exclusivamente ao pesquisador responsável pelo estudo popularizado e ao colega especialista na mesma área do estudo, conforme resultados prévios acima mencionados. Essa exclusão de outros setores da sociedade, como o governo ou o público, indica a ênfase na autoridade do cientista e posiciona, no topo da hierarquia entre os participantes, especialistas com voz no texto, enquanto o público leitor é posicionado na base de tal hierarquia, conforme discutido na seção 3.1 .

Em relação à análise das projeções ${ }^{6}$, podemos dizer, sob a perspectiva da Avaliatividade, que o discurso científico é recontextualizado, nas notícias do corpus, principalmente pelo recurso de expansão dialógica por atribuição-reconhecimento. Considerando as 481 ocorrências de projeções no corpus, verificamos que, em grande parte, o jornalista lança mão de recursos de atribuição-reconhecimento (393 ocorrências) e atribuiçãodistanciamento (26 ocorrências), enquanto o recurso de contração dialógica ratificação-endosso aparece em poucas projeções (62 ocorrências).

Os expoentes linguísticos desses três recursos do engajamento foram identificados segundo o tipo de processo (Sistema de Transitividade) descrito em Halliday e Matthiessen (2004) e as definições em inglês e em português encontradas em dicionários gratuitos, disponíveis online $^{7}$. Essas definições e estudos prévios (MOTTA-ROTH; MARCUZZO, 2010; NASCIMENTO, 2011) auxiliaram na classificação daqueles processos não mencionados em Halliday e Matthiessen (2004) ou no esclarecimento de ambiguidades, sempre levando em consideração o contexto em que aparecem no corpus.

\footnotetext{
6. Nesta análise dos expoentes linguísticos de engajamento em projeções (citação e relato), a projeção foi, em si, o primeiro critério considerado na identificação e classificação dos expoentes linguísticos. Segundo Motta-Roth e Marcuzzo (2010, p. 528, parafraseando HALLIDAY e MATTHIESSEN, 2004, p. 448), uma oração projetada "só é possível com processos verbais e mentais".

7. Todas as definições em inglês deste trabalho foram retiradas do dicionário online Merriam-Webster. Disponível em <http://www.merriam-webster.com/>. As definições em português foram retiradas do dicionário online Priberam da Língua Portuguesa. Disponível em <http://www.priberam.pt/dlpo>.
} 
Embora os recursos de expansão sejam mais recorrentes, essa expansão do discurso é apenas aparente, uma vez que, conforme aponta Marcuzzo (2011) a partir da análise do mesmo corpus, a promoção de um debate envolvendo representantes dos diferentes setores da sociedade em torno de questões científicas não acontece nessas notícias de PC. Em vez disso, o jornalista apresenta a pesquisa a partir de um ponto de Anelise vista apenas (o científico), posicionando-se pouco em relação a este no texto. Quando há posicionamento do jornalista em relação ao discurso representado (ratificação-endosso, no caso da contração, ou atribuição-

Désirée -distanciamento, no caso da expansão), observamos o alinhamento à Motta-Roth voz do cientista (ratificação-endosso) ou um afastamento apenas aparente, pois a modalização na voz do jornalista (oração projetante) presente nos casos de atribuição-distanciamento parece emular o discurso modalizado do especialista (oração projetada).

A representação do discurso do outro (projeções) em nossas notícias de PC é realizada por meio de citações e relatos que omitem ou indicam o posicionamento do jornalista em relação ao discurso do especialista. Dentre essas duas possibilidades, o recurso de expansão dialógica que omite o posicionamento do jornalista (atribuição-reconhecimento) é mais recorrente. No entanto, argumentamos que o recurso de atribuição-reconhecimento em notícias de PC não se presta a expandir o discurso efetivamente, uma vez que a quase exclusividade de vozes do contexto científico (o pesquisador e o colega) corrobora apenas um ponto de vista: o da ciência. Essa ideia pode ser confirmada, também, a partir dos dados referentes aos recursos de atribuição-distanciamento e ratificação-endosso, os quais reportamos mais adiante. Poder-se-ia pensar que outros segmentos da sociedade, como o governo e principalmente o público, poderiam oferecer importantes testemunhos e avaliações acerca da recepção ou dos efeitos das inovações científicas na sociedade.

Em relação ao recurso de expansão atribuição-reconhecimento, identificamos, nos textos do nosso corpus, 23 expoentes linguísticos, que correspondem a processos verbais (tais como say, report e write), processos mentais (tais como believe, think e agree), e circunstâncias de ângulo (tais como according to). Esses expoentes linguísticos correspondem a 383 ocorrências de projeção, das quais, 304 são ocorrências do processo verbal say. Esse processo, portanto, pode ser considerado prototípico em relação a esse recurso: 
o processo say é considerado um processo verbal não marcado

(HALLIDAY; MATTHIESSEN, 2004, p. 252) ou neutro, na medida em que introduz uma locução sem avaliá-la (CALDAS-COULTHARD, 1994, p. 305). (MOTTA-ROTH; MARCUZZO, 2010, p. 528).

No Exemplo 2, percebemos que a ideia de "produzir sentido" atribuído a ambos os processos verbais say e note implica neutralidade em relação ao posicionamento do jornalista relativo ao discurso do cientista.

\section{Exemplo 2:}

"I think this paper's going to have a very short half-life," says Ralph Mistleberger, who studies circadian rhythms at Simon Engajamento e redução do espaço dialógico no gênero notícia de popularização científica Fraser University in Burnaby, British Columbia. Mistleberger notes that Bmal1-deficient mice are not particularly healthy, and that the extent of the study's food restrictions may stress the mice so much as to skew the results (Nat\#4).

O jornalista não modaliza seu discurso, apenas atribui o discurso ("I think this paper's going to have a very short half-life," e that Bmal1-deficient mice are not particularly healthy, and (...)) a uma voz externa que o proferiu (Ralph Mistleberger(...)). Se o jornalista explicitasse seu afastamento $\mathrm{da} /$ forte alinhamento à posição do Dizente (por meio de operadores modais finitos como might/must) ou MGI (como Ralph Mistleberger suggests/guarantees that) na oração projetante, essa não seria uma ocorrência de atribuição-reconhecimento, mas sim de atribuição-distanciamento ou de ratificação-endosso, respectivamente (Exemplo 3).

Exemplo 3:

The team took white blood cells from 21 patients, exposed them to parts of the virus, and injected the cells back into the patients. Their preliminary results suggest that this technique is safe and effective.

"Because the immune system kills both the virus and the cell it resides in, we are hoping that we will be able use this vaccine to kill the tumour cells that standard therapy can't reach," explains Mitchell. (Nat\#3) 
No primeiro caso de projeção do Exemplo 3, o jornalista lança dúvida em relação ao discurso assertivo (this technique is safe and effective) do especialista representado metaforicamente pelos resultados do estudo (SANTOS, 2010) a partir da modalização na oração projetante (MGI suggest), expandindo o espaço dialógico. No segundo caso, a questão é inversa: o jornalista ratiAnelise fica (explains, na oração projetante) o discurso do especialista de modo a não Scotti Scherer

Désirée admitir outras possibilidades de posicionamento (contração dialógica).

Em relação aos expoentes linguísticos de atribuição-distanciamento e Motta-Roth de ratificação-endosso, encontramos, nesta análise, principalmente ocorrências de processos verbais não prototípicos e mentais cognitivos associados a projeções que realizam atribuição-distanciamento e processos verbais ${ }^{8}$ e processos mentais cognitivos associados a projeções que realizam ratificação-endosso (Quadro 3).

$\mathrm{O}$ alinhamento do jornalista, indicado pelos processos associados à atribuição-distanciamento, corresponde a um afastamento em relação ao discurso representado, uma vez que esses processos sinalizam uma possibilidade (baixo grau de assertividade), não uma certeza e, em tese, expandem o espaço dialógico.

\begin{tabular}{|l|l|l|}
\hline \multicolumn{2}{|c|}{ EXPOENTE LINGUÍSTICo } & \multirow{2}{*}{ CATEGORIA LEXICOGRAMATICAL } \\
\cline { 1 - 2 } Atribuição-distanciamento & Ratificação-endosso & \\
\hline suggest; imply & show; indicate & processo verbal (não prototípico) \\
\hline & explain; argue; warn & processo verbal - circunstância \\
\hline speculate; suspect; theorize & $\begin{array}{l}\text { feveal; point (out) } \\
\text { conclude; admit }\end{array}$ & processo verbal - declaração \\
\hline hope & processo mental - cognitivo \\
\hline
\end{tabular}

Quadro 3 - Expoentes linguísticos que realizam atribuição por distanciamento e ratificação por endosso no corpus

Já os processos associados a ratificação-endosso marcam a contração do espaço discursivo ao representar o discurso do outro como única possibilidade válida (alto grau de assertividade). Esse grau de assertividade atribuído aos processos pode ser verificado a partir de seus significados, no Quadro 4.

8. Ver seção 1.2.1. 


\begin{tabular}{|c|c|}
\hline Atribuição-distanciamento & Ratificação-endosso \\
\hline \multicolumn{2}{|c|}{ Processos verbais (say) } \\
\hline $\begin{array}{l}\text { - suggest: considerar como } \\
\text { possibilidade, hipótese } \\
\text { - imply: considerar por meio } \\
\text { de inferência. } \\
\text { - } \quad \text { speculate: formar ideias in- } \\
\text { conclusivas } \\
\text { - } \quad \text { suspect: formar ideias in- } \\
\text { certas, passíveis de dúvida } \\
\text { - theorize: formar ideias por } \\
\text { teoria sem comprovação } \\
\text { - hope: formar ideias com } \\
\text { base em desejo }\end{array}$ & 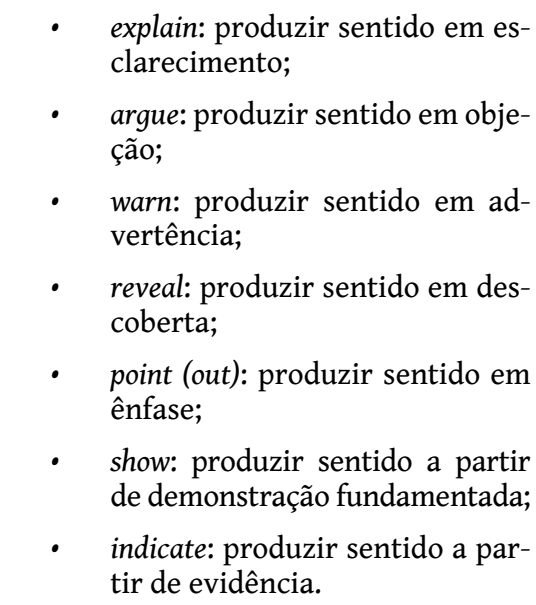 \\
\hline \multicolumn{2}{|c|}{ Processos mentais (think) } \\
\hline & $\begin{array}{l}\text { - find: formar ideias em termos de } \\
\text { descoberta via experimento; } \\
\text { - discover: formar ideias em ter- } \\
\text { mos de descobrimento; } \\
\text { - know: formar ideias em termos } \\
\text { de entendimento; } \\
\text { - conclude: formar ideias em ter- } \\
\text { mos de revelação; } \\
\text { - admit: formar ideias em termos } \\
\text { de reconhecimento de validade; } \\
\text { calculate: formar ideias em ter- } \\
\text { mos de cálculo. }\end{array}$ \\
\hline
\end{tabular}

Quadro 4 - Processos que realizam atribuição-distanciamento e ratificação-endosso ${ }^{9}$

9. Definições elaboradas a partir de dicionário, conforme explicado na nota 15 acima. 
Dentre os expoentes linguísticos das 26 ocorrências de expansão dialógica por atribuição-distanciamento no corpus (Tabela 1), percebemos que o processo suggest é o mais frequente. Há também diferenças em termos de subcorpora, pois os textos das publicações Scientific American e ABC Science apresentam uma frequência mais baixa do que o subcorpus da Nature, sugerindo que o jornalista desta publicação posiciona-se/afasta-se mais das outras

Anelise vozes reportadas/citadas por ele.

Scotti Scherer

Désirée

Motta-Roth

Tabela 1 - Frequência de atribuição-distanciamento no corpus

\begin{tabular}{|c|r|r|r|r|r|r|r|r|r|}
\hline \multicolumn{4}{|c|}{ PROCESSOS VERBAIS } & \multicolumn{4}{|c|}{ PROCESSOS MENTAIS } \\
\hline $\begin{array}{c}\text { Exp. } \\
\text { linguís- } \\
\text { tico }\end{array}$ & SciAm & ABC & Nat & TOTAL & $\begin{array}{c}\text { Exp. } \\
\text { linguís- } \\
\text { tico }\end{array}$ & SciAm & ABC & Nat & TOTAL \\
\hline suggest & 1 & 5 & 11 & 17 & $\begin{array}{c}\text { specu- } \\
\text { late }\end{array}$ & 3 & 1 & 1 & 5 \\
\hline imply & 1 & - & - & 1 & suspect & - & 1 & - & 1 \\
\hline \multirow{2}{*}{ TOTAL } & & & & & theorize & - & - & 1 & 1 \\
\cline { 5 - 10 } & & 5 & 11 & 18 & hope & - & - & 1 & 1 \\
\cline { 5 - 10 } & & & & & TOTAL & 3 & 2 & 3 & 8 \\
\hline
\end{tabular}

De modo a identificar o grau de distanciamento do jornalista, retomemos a primeira projeção no Exemplo 3 (Their preliminary results suggest that this technique is safe and effective) para analisá-la em comparação com as situações dos Exemplos 4 e 5.

Exemplo 4:

These same clock genes are in all mammals, including humans. Therefore, Saper suggests that it may be possible to override the body's natural circadian clock by not eating for an extended period. (ABC\#3)

Exemplo 5:

Three further hair samples from the same site exist and the researchers hope these will yield more information. (Nat\#10) 
A partir dessa comparação, tecemos três observações. Em primeiro lugar, no Exemplo 4, o processo relacional suggest introduz a implicação da pesquisa relatada na voz do pesquisador como uma possibilidade de aplicação desses resultados, obtidos com ratos, a seres humanos. Ao usar suggest, o jornalista demonstra um grau menor de alinhamento (ou distanciamento) com o discurso do pesquisador, uma vez que esse processo remete a "insinuar", "mencionar como uma possibilidade ou hipótese", logo a verificação desses resultados em humanos pode não acontecer.

Entretanto, o que nos chama atenção é o fato de o discurso representado já ter sido modalizado pelo pesquisador (may be possible, na oração projetada): a incerteza quanto às implicações do estudo para os humanos aparece no discurso creditado ao pesquisador, antes de ser marcada na voz do jornalista. Ocorre, portanto, uma harmonia prosódica entre o que se supõe serem duas vozes - jornalista e pesquisador. Assim o significado interpessoal (a baixa assertividade) é tecido ao longo de toda a sentença, como uma forma de expressão contínua, sem fronteiras determinadas (em oposição ao significado ideacional, que é particularizado em cada elemento - participante, processo e circunstância - da Transitividade) (HALLIDAY, 1994, p. 35; MARTIN; WHITE, 2005, p. 18-19; MARTIN, 1992, p. 10-13), como uma onda de avaliação que se espalha por toda essa estrutura hipotática.

Em segundo lugar, na primeira projeção no Exemplo 3, suggest também é usado para demarcar o distanciamento do jornalista em relação à proposição atribuída metaforicamente à voz do pesquisador por meio dos resultados do estudo (Their preliminary results suggest that). 0 discurso representado (oração projetada) não é modalizado, porque se refere, não aos resultados, mas aos procedimentos efetivamente realizados no estudo.

Em terceiro lugar, no Exemplo 5, contrastando com a assertividade do discurso reportado (...these will yield more information), o jornalista usa o processo mental hope para se referir às expectativas dos pesquisadores, indicando que estas ainda não foram comprovadas, são apenas uma dentre várias possibilidades.

Em tese, ambos os recursos de atribuição (distanciamento e reconhecimento) seriam marcas de expansão dialógica (MARTIN; WHITE, 2005), segundo as quais o discurso é expandido de forma a considerar posicionamento alternativo. Entretanto, ao considerarmos os Exemplos 3, 4 e 5 de forma combinada, a interpretação sofre alterações. Isso acontece 
Anelise

Scotti Scherer

Désirée

Motta-Roth

porque nem sempre a modalização, responsável pelo distanciamento do jornalista em relação ao discurso representado, ocorre na voz do próprio jornalista, mas sim na voz do pesquisador, conforme ilustra o Exemplo 4. Considerando esses casos em que a modalização (p. ex., suggest como marca de distanciamento) no discurso do jornalista é guiada pela modalização no discurso dos próprios pesquisadores (p. ex., operador modal finito may), podemos dizer que o posicionamento do jornalista está atrelado (ou mesmo subjugado) ao discurso (posicionamento) do pesquisador. Isso sugere um efeito de monologismo, pois, embora haja marcas tipicamente atribuídas à expansão dialógica, quando considerado o co(n)texto, verifica-se que o discurso é contraído, o espaço dialógico é restrito a um ator social, o cientista (vozes do pesquisador e do colega).

Diferentemente o recurso de ratificação-endosso é classificado por Martin e White (2005) como um dos recursos da contração dialógica. Isso se deve ao fato de que, ao endossar o conteúdo da proposição projetada, o jornalista representa-a como única posição válida, alinhando-se ao discurso alheio, sem que haja espaço para posições alternativas. A partir da apuração da frequência dos expoentes linguísticos de ratificação-endosso no corpus (Tabela 2), identificamos os processos verbais explain e show e o processo mental find como marcas recorrentes do alto grau de alinhamento da voz do jornalista à voz do outro.

Tabela 2 - Frequência de ratificação-endosso no corpus

\begin{tabular}{|l|l|l|l|l|l|l|l|l|l|}
\hline \multicolumn{9}{|l|}{ PROCESSOS VERBAIS } & \multicolumn{5}{l|}{ PROCESSOS MENTAIS } \\
\hline $\begin{array}{l}\text { Exp. lin- } \\
\text { guístico }\end{array}$ & SciAm & ABC & Nat & $\begin{array}{l}\text { TO- } \\
\text { TAL }\end{array}$ & $\begin{array}{l}\text { Exp. lin- } \\
\text { guístico }\end{array}$ & SciAm & ABC & Nat & $\begin{array}{l}\text { TO- } \\
\text { TAL }\end{array}$ \\
\hline explain & 6 & 2 & 7 & 15 & find & 5 & 5 & 2 & 12 \\
\hline warn & 1 & - & - & 1 & know & 1 & 2 & 2 & 5 \\
\hline reveal & - & 1 & - & 1 & discover & 2 & 2 & - & 4 \\
\hline point out & - & - & 1 & 1 & admit & 2 & - & - & 2 \\
\hline show & 4 & 4 & 5 & 13 & conclude & 1 & - & - & 1 \\
\hline indicate & 2 & - & 1 & 3 & calculate & - & 1 & - & 1 \\
\hline TOTAL & 13 & 7 & 14 & 34 & TOTAL & 11 & 10 & 4 & 25 \\
\hline
\end{tabular}

No Exemplo 6, o processo verbal explain é usado para introduzir um comentário sobre a pesquisa, a partir do qual o pesquisador compara o conhecimento estabelecido com os achados do estudo sendo popularizado. Essa comparação é feita de modo a esclarecer os resultados do 
estudo para a audiência não especializada, coforme indica o processo explain (dizer para esclarecimento). Na comparação, o pesquisador refere-se ao fluxo de energia no sistema fotossintético de uma bactéria como o fluxo do trânsito em um cruzamento (intersection; path).

Exemplo 6:

"We always thought of it [flow of energy through the bacterium's photosynthetic system] as hopping through the system, the same way that you or I might run through a maze of bushes," Engel explains. "But, instead of coming to an intersection and going left or right, it can actually go in both directions at once and explore many different paths most efficiently."(SciAm\#1)
Engajamento

e redução do espaço dialógico no gênero notícia de popularização científica

Conforme a definição fornecida no Quadro 4, explain significa "produzir sentido em esclarecimento", ou, no dicionário online, "mostrar o desenvolvimento lógico ou as relações de; esclarecer as declarações de alguém". Considerando que, para esclarecer uma questão, é preciso que haja conhecimento sobre o assunto e clareza para que não haja espaço para dúvidas, ao usar o processo verbal explain, o jornalista marca o seu posicionamento como mais alinhado possível ao discurso representado (autoridade máxima do pesquisador).

No Exemplo 7, o processo mental cognitivo find é usado no particípio passado (have found) para indicar as conclusões da pesquisa no lide da notícia, na voz do pesquisador (researchers). Nesse caso, as conclusões são acompanhadas de dados numéricos referentes à descoberta.

Exemplo 7:

Microbes have created a home in 111-million-year-old rock buried 1.6 kilometres below the sea floor, researchers have found. (Nat\#6)

Também, ao usar o processo find, o jornalista abre o espaço dialógico apenas para o discurso do pesquisador, indicando precisão ou buscando excluir a possibilidade de erro, uma vez que as conclusões da pesquisa são formuladas em termos numéricos. Assim, essas evidências quantitativas contribuem para ratificar a autoridade do pesquisador. 
Em geral, nas projeções analisadas, a alta ocorrência de atribuição-reconhecimento e a baixa ocorrência de atribuição-distanciamento e de ratificação-endosso sugerem um baixo (ou quase inexistente) posicionamento do jornalista em relação ao discurso citado e/ou relatado. Esses resultados reforçam a autoridade máxima conferida apenas às fontes científicas. Quanto mais especializado for o autor da notícia Anelise de PC, maior será a possibilidade de posicionamento em relação ao discurso citado ou reportado. Isso não significa, necessariamente, que o jornalista mais especializado optará pelo dialogismo na notícia de PC, Désirée estabelecendo a interação de diferentes pontos de vista. Ao contrário, o Motta-Roth que se percebe a partir desta análise é que nem mesmo jornalistas especializados, como os da publicação Nature (GERHARDT, 2011), chegam a promover um debate efetivo.

Com base na análise do contexto das publicações e dos recursos de engajamento referentes à inserção de diferentes vozes nos exemplares do gênero notícia de PC, Scherer (2013, p. 158) sintetiza, no Quadro 5 , os aspectos do contexto e do texto que nos permitem localizar as publicações em um contínuo de PC (HILGARTNER, 1990). De acordo com evidências coletadas nos sites das publicações (GERHARDT, 2011) e na análise das projeções nos textos do corpus, Scherer (2013) identifica a publicação Scientific American como ocupante de um lugar intermediário entre as publicações $A B C$ Science (mais popular, menos científica) e Nature (menos popular, mais científica).

\begin{tabular}{|c|c|c|c|}
\hline PUBLICAÇÃO & Q & $\begin{array}{l}\text { SCIENTIFIC } \\
\text { AMERICAN }^{\mathrm{m}}\end{array}$ & nature.con \\
\hline $\begin{array}{c}\text { EVIDÉNCIAS DO } \\
\text { GRAU DE } \\
\text { POPULARIZAÇA/ } \\
\text { CIENTIFICIDADE }\end{array}$ & $\begin{array}{l}\text { jornalista não especialista; leitor } \\
\text { não especialista } \\
\text { maior predominância de } \\
\text { projeçōes ( } 54,7 \%) \\
\text { presença da voz do público } \\
\text { (participante da pesquisa) e } \\
\text { maior predominância da voz do } \\
\text { pesquisador }(83,3 \%) \text { em relação } \\
\text { ao colega (12,5\%) } \\
\text { menor explicitação do do } \\
\text { posicionamento do jornalista ( } 24 \\
\text { ocorrências de distanciamento e } \\
\text { endosso) ou maior alinhamento } \\
\begin{array}{l}\text { da posiçāo do jornalista em } \\
\text { telação à do pesquisador }\end{array}\end{array}$ & $\begin{array}{l}\text { - jornalista especialista; leitor não } \\
\text { especialista } \\
\text { - predominância média de } \\
\text { projeçōes }(51,2 \%) \\
\text { - presencnca da voz do governo } \\
\text { (cientista a serviço do governo)e } \\
\text { predominância média da voz do } \\
\text { pesquisador }(66,7 \%) \text { em relação } \\
\text { ao colega }(25,9 \%) \\
\text { - explicitacão média do } \\
\text { posicionamento do jornalista (31 } \\
\text { ocorrências de distanciamento e } \\
\text { endosso) ou médio alinhamento } \\
\text { da posiçào do jornalista em } \\
\text { relação à do pesquisador }\end{array}$ & $\begin{array}{l}\text { - jornalista especialista; leitor } \\
\text { especialista } \\
\text { - menor predominância de projeçães } \\
(34,3 \%) \\
\text { - ausência de vozes além do } \\
\text { pesquisador e do colega e e } \\
\text { Predominância baixa da voz do } \\
\text { pesquisador (58\%) em relação ao } \\
\text { colega (42\%) } \\
\text { - maior explicitação do do } \\
\text { posicionamento do jornalista (33 } \\
\text { ocorrências de dsitanciamento e } \\
\text { endosso) ou menor alinhamento da } \\
\text { posiçāo do jornalista em relaçāo à } \\
\text { do pesquisador }\end{array}$ \\
\hline
\end{tabular}

Quadro 5 - Evidências do grau de popularização/cientificidade das notícias do corpus (SCHERER, 2013, p. 158) 
Nesse sentido, os resultados da análise dos expoentes linguísticos de engajamento confirmam o efeito de monologismo apontados em trabalhos prévios do GT-LABLER sobre o gênero notícia de PC (p. ex., MOTTA-ROTH, 2009; NASCIMENTO, 2011; MARCUZZO, 2011) ao comprovar que "citação e relato de declarações de atores sociais ligados à ciência constituem-se em recurso de autoridade que empresta legitimidade à notícia e reduz a heterogeneidade discursiva" (MOTTA-ROTH; LOVATO, 2011, p. 264).

Podemos dizer, portanto, que a maioria os dados e exemplos explorados neste artigo são realizações apenas aparentes da expansão dialógica em notícias de PC. Essa contração do discurso é evidenciada, principalmente, pelo fato de as vozes serem quase exclusivamente de representantes da comunidade científica e, normalmente, não defen-

Engajamento e redução do espaço dialógico no gênero notícia de popularização científica derem opiniões divergentes, mas concordantes umas com as outras. Assim, podemos entender o efeito de monologismo como um efeito de eco, em que a reflexão de um mesmo som (neste caso, a representação do discurso do cientista) é percebida posteriormente, distinguindo-se do som original apenas temporalmente, como se fossem respostas aos sons emitidos anteriormente, sem, no entanto, configurar um som diferente (discurso do jornalista ou a representação do discurso de outros setores da sociedade), produzindo uma harmonia prosódica ao longo do texto.

\section{Considerações finais e possibilidades de diálogo}

Com este estudo, buscamos mapear, em notícias de PC em inglês, os expoentes linguísticos dos recursos de engajamento associados a projeções que evidenciassem o efeito de monologismo em notícias de PC. Embora a investigação dos expoentes linguísticos de engajamento tenha evidenciado o uso de recursos típicos da expansão dialógica (reconhecimento e distanciamento) nos textos do corpus, a predominância da voz do pesquisador entra em conflito com a função desses recursos heteroglóssicos (de expandir o espaço discursivo) ao estabelecer apenas um ponto de vista em relação à pesquisa popularizada (o do especialista), marcas do caráter hegemônico do discurso científico.

Nosso estudo apresenta um enfoque limitado em relação ao universo complexo da $\mathrm{PC}$ e das várias práticas sociais que compõem a espiral da produção, divulgação e circulação científica (MOREIRA, 2012, com base em VOGT, 2003). Algumas dessas limitações envolvem um recorte de pesquisa restrito em termos do tamanho do corpus e das categorias de engajamento considerados 
na análise bem como em relação à dificuldade de classificação/interpretação dos expoentes linguísticos, pois, na medida em que nos aprofundávamos nas questões da Avaliatividade (engajamento) e dialogismo, mais questionamentos surgiam em relação à identificação de suas marcas no corpus.

Esperamos, portanto, que a descrição dos expoentes linguísticos de engajamento analisados por nós possa servir a outras empreitadas

Anelise científicas à luz da Avaliatividade ou que enfoquem diferentes gêneScotti Scherer

Désirée não foram abordadas neste estudo, sugerimos, como diálogo possível com Motta-Roth ros discursivos da PC. Considerando que o subsistema de engajamento fornece uma gama de categorias pertinentes à análise das práticas sociais de PC que essa pesquisa, mapeamentos dos expoentes linguísticos de engajamento que enfoquem, por exemplo, outros recursos da contração dialógica (tais como a contestação e a concordância); orações e complexos oracionais em que não há projeção (voz do jornalista), contrastando notícias de PC em inglês e em português para fins de comparação. Além dessas possibilidades, conforme prevê o projeto guarda-chuva, esperamos que os resultados desta pesquisa possam servir como subsídios na elaboração de propostas didáticas, à luz da LSF, de ensino de língua inglesa como língua adicional.

\section{Referências}

BAKHTIN, M. Estética da criação verbal. São Paulo: Martins Fontes, 1952-1953/2010.

BEACCO, J.-C. et al. Science in media and social discourse: new channels of communication, new linguistic forms. Discourse Studies, v. 4, n. 3, p. 277-300, 2002.

BERNSTEIN, B. Class, codes and control, v. 1: Theoretical studies towards a sociology of language. 2. ed. London: Routledge \& Kegan Paul, 1974.

BERTRAND, C.-J. A deontologia das mídias. Bauru: EDUSC, 1999.

BRAIT, B. (Org.). Bakhtin: dialogismo e polifonia. São Paulo: Contexto, 2009.

CALSAMIGLIA, H.; VAN DIJK, T. Popularization discourse and knowledge 
about the genome. Discourse Studies, v. 15, n. 4, p. 369-389, 2004.

FARACO, C. Linguagem e diálogo: as ideias do círculo de Bakhtin. São Paulo: Parábola, 2009.

GEE, J. P. How to do discourse analysis: a toolkit. New York: Routledge, 2011.

GERHARDT, L. B. A didatização do discurso da ciência na mídia eletrônica. Tese (Doutorado em Letras) - Santa Maria: Programa de Pós-Graduação em Letras, Universidade Federal de Santa Maria, 2011.

HALLIDAY, M. A. K. An introduction to functional grammar. 2.

ed. London: Edward Arnold, 1994.

HALLIDAY, M. A. K.; HASAN, R. Language, context, and text: aspects of language in a social-semiotic perspective. Oxford: Oxford University Press, 1989.

HALLIDAY, M. A. K.; MATTHIESSEN, C. M. I. M. An introduction to functional grammar. 3. ed. London: Hodder Arnold, 2004.

HILGARTNER, S. The dominant view of popularization: conceptual problems, political uses. Social Studies of Science, v. 20, n. 3, p. 519-139, 1990.

LOVATO, C. dos S. Análise de gênero: investigação da organização retórica do gênero notícia de popularização da ciência. Dissertação (Mestrado em Letras) - Santa Maria: Programa de Pós-Graduação em Letras, Universidade Federal de Santa Maria, 2010.

MARCUZZO, P. Ciência em debate? Análise do gênero notícia de popularização científica. Tese (Doutorado em Letras) - Santa Maria: Programa de Pós-Graduação em Letras, Universidade Federal de Santa Maria, 2011.

MARQUES, P. M.; MOTTA-ROTH, D.; HENDGES, G. R. O gênero notícia de popularização da ciência sob a perspectiva da multimodalidade. 
In: JORNADA ACADÊMICA INTEGRADA (JAI), 25., 2010, Santa Maria, RS. Anais... Santa Maria: UFSM/JAI, 2010. Disponível em: <http:// portal.ufsm.br/jai2010/anais/trabalhos/trabalho_1041243860.htm>. Acesso em: 10 fev. 2013.

Anelise

MARTIN, J. R. English text: system and structure. Philadelphia/ Scotti Scherer

Désirée in English. London: Continuum, 2005.

Motta-Roth

MEURER, J. L. Integrando estudos de gêneros textuais ao contexto de cultura. In: KARWOSKI, A.; GAYDECKA, B.; BRITO, K. S. (Orgs.). Gêneros textuais: reflexões e ensino. 2. ed. Rio de Janeiro: Lucerna, 2006. p. 165-185.

MOIRAND, S. Communicative and cognitive dimensions of discourse on science in the French mass media. Discourse Studies, v. 5, n. 2, p. 175-206, 2003.

MOREIRA, T. M. Análise crítica de gêneros de popularização da ciência da área de informática no jornal Zero Hora (2009). Tese (Doutorado em Letras) - Santa Maria: Programa de Pós-Graduação em Letras, Universidade Federal de Santa Maria, 2012.

MOREIRA, T. M.; MOTTA-ROTH, D. Popularização da ciência: uma visão panorâmica do Diário de Santa Maria. In: CÍRCULO DE ESTUDOS LINGUÍsTICOS DO SUL (CELSUL), 8., 2008, Porto Alegre. Anais... Porto Alegre: UFRGS/CELSUL, 2008. 1 CD-ROM.

MOTTA-ROTH, D. Análise crítica de gêneros com foco em artigos de popularização da ciência. Santa Maria: Universidade Federal de Santa Maria, 2007. Projeto de Produtividade em Pesquisa PQ/ CNPq (no 301962/2007- 3).

Análise crítica de gêneros: contribuições para o ensino e a pesquisa de linguagem. D.E.L.T.A., v. 24, n. 2, p. 341-383, 2008. 
A popularização da ciência como prática social e discursiva. In: Motta-Roth, D.; Giering, Maria Eduarda (Orgs.). Discursos de popularização da ciência. Santa Maria, RS: PPGL Editores, 2009. p. 130-195 (Coleção HiperS@beres, 1). Disponível em: <http://w3.ufsm. br/hipersaberes/volumeI/>. Acesso em: 04 abr. 2012.

MOTTA-ROTH, D.; LOVATO, C. dos S. Organização retórica do gênero notícia de popularização da ciência: um estudo comparativo entre Português e Inglês. Linguagem em (Dis)curso, v. 9, n. 2, p. 233-271, 2009.

. O poder hegemônico da ciência no discurso de popularização científica. Calidoscópio, v. 9, n. 3, p. 251-268, 2011.

Engajamento e redução do espaço dialógico no gênero notícia de popularização científica

MOTTA-ROTH, D.; MARCUZZO, P. Ciência na mídia: análise crítica de gêneros de notícias de popularização científica. Revista Brasileira de Linguística Aplicada, v. 10, n. 3, p. 511-538, 2010.

MOTTA-ROTH, D. et al. Polifonia em notícias de popularização da ciência sob a ótica sistêmico-funcional. In: CONGRESSO DA ASSOCIAÇÃO DE LINGUÍSTICA SISTÊMICO-FUNCIONAL DA AMÉRICA LATINA (ALSFAL), 4., 2008, Florianópolis, SC. Anais... Florianópolis, SC: ALSF AL/PPGI-CCE-UFSC, 2008. p. 133-146.

MOTTA-ROTH, D.; SCHERER, A. S. Expansão e contração dialógica na mídia: intertextualidade entre ciência, educação e jornalismo. D.E.L.T.A., v. 27, n. esp., 2012.

MOTTA-ROTH, D.; SOCOLOSKI, T. da S. Perspectivas analíticas e pedagógicas de textos eletrônicos de popularização da ciência. In: SIGET-SIMPÓSIO INTERNACIONAL DE ESTUDOS DE GÊNEROS TEXTUAIS, 5., 2009, Caxias do Sul. Caderno de Resumos... Caxias do Sul: EDUCS, 2009, p. 19.

MYERS, G. Discourse studies of scientific popularization: questioning the boundaries. Discourse Studies, v. 5, n. 2, p. 265-279, 2003.

NASCIMENTO, F. S. 'GM crops may be harmful to the environment': graus de autoridade e assertividade em notícias de popularização 
da ciência. Dissertação (Mestrado em Letras) - Santa Maria: Programa de Pós-Graduação em Letras, Universidade Federal de Santa Maria, 2011.

OLIVEIRA, J. M.; PAGANO, A. S. The research article and the science popularization article: a probabilistic functional grammar perspec-

Anelise tive on direct discourse representation. Discourse Studies, London, Scotti Scherer v. 8, n. 5, p. 627-646, 2006.

Désirée PAGANO, A. Genes, ovelhas e discos compactos: alguns aspectos das Motta-Roth reescritas de descobertas científicas. In: MACHADO, I.; L. CRUZ, A.; LYSARDO-DIAS, D. Teorias e práticas discursivas: estudos em análise do discurso. Belo Horizonte: UFMG/Carol Borges, 1998. p. 55-72.

PINTON, F. M. O jornalista, o especialista e o professor leitor: relações diretivas na revista Nova Escola. Revista E-scrita: revista do curso de Letras da UNIABEU, v. 4, p. 95-110, 2013.

SANTOS, R. L. dos. Metáforas lexicais em estruturas verbais e mentais em notícias de popularização da ciência. Dissertação (Mestrado em Letras). Santa Maria, RS: Programa de Pós-Graduação em Letras, Universidade Federal de Santa Maria, 2010.

SCHERER, A. S. Engajamento e efeito de monologismo no gênero notícia de popularização científica. Dissertação (Mestrado em Letras). Santa Maria, RS: Programa de Pós-Graduação em Letras, Universidade Federal de Santa Maria, 2013.

VIAN JR, O. Engajamento: monoglossia e heteroglossia. In: Orlando Vian Jr; Anderson Alves de Souza; Fabíola Sartin Dutra Parreira Almeida. (Orgs.). A linguagem da avaliação em língua portuguesa: estudos sistêmico-funcionais com base no Sistema da Avaliatividade. São Carlos: Pedro \& João Editores, 2010. p. 33-40.

VAN DIJK, T. A. Estruturas da notícia na imprensa. In: VAN DIJK, T. A. Cognição, discurso e interação. São Paulo: Contexto, 1999. p. 122-157. 
VOGT, C. A. A espiral da cultura científica. ComCiência - Revista Eletrônica de Jornalismo Científico, Campinas, n. 45, 2003. Disponível em: <http:// www.comciencia.br/reportagens/ultura/cultura01.shtml>. Acesso em: 15 ago 2015.

VOLOCHINOV, V. N. Marxismo e filosofia da linguagem. 7. ed. São Engajamento Paulo, Hucitec. 1995.

e redução do

espaço dialógico

no gênero notícia

de popularização científica 
Anelise

Scotti Scherer

Désirée

Motta-Roth

302

Letras, Santa Maria, v. 25, n. 50, p. 261-302, jan./jun. 2015 